\title{
Adaption of Norway spruce and European beech forests under climate change: from resistance to close-to-nature silviculture
}

\author{
Zdeněk Vacek ${ }^{1, *}$, Stanislav Vacek ${ }^{1}$, Jiří Slanař ${ }^{1}$, Lukáš Bílek ${ }^{1}$, Daniel Bulušek ${ }^{1}$, \\ Igor Štefančík ${ }^{2}$, Ivo Králíček ${ }^{3}$, Karel Vančura ${ }^{1}$ \\ ${ }^{1}$ Czech University of Life Sciences Prague, Faculty of Forestry and Wood Sciences, Kamýcká 129, \\ CZ - 16521 Prague 6 - Suchdol, Czech Republic \\ ${ }^{2}$ National Forest Centre, Forest Research Institute, T. G. Masaryka 2175/22, SK-960 01 Zvolen, Slovak Republic \\ ${ }^{3}$ University of Hradec Králové, Faculty of Science, Rokitanského 62, CZ - 50003 Hradec Králové, Czech Republic
}

\begin{abstract}
In time of climate change, close-to-nature silviculture is growing in importance as a tool for future forest management. The paper study the tree layer and natural regeneration of monospecific Norway spruce (Picea abies [L.] Karst.), trough mixed spruce-beech to dominant European beech (Fagus sylvatica L.) forests in Jizerské hory Mts., the Czech Republic. In the locality, shelterwood and selection system have been applied since 2000. The research objectives were to evaluate production parameters, structural diversity, species richness, natural regeneration dynamics and radial growth of individual tree species in relation to climatic factors and air pollution. The stand volume on permanent research plots amounted to $441-731 \mathrm{~m}^{3} \mathrm{ha}^{-1}$ in initial stage of transformation. Natural regeneration showed high expansion of beech and decrease of spruce compared to mature tree species composition. Radial growth of spruce was in significant negative correlation with $\mathrm{SO}_{2}$ and $\mathrm{NO}_{\mathrm{x}}$ concentrations compared to no effect on beech increment. Moreover, spruce was more sensitive to significant years with extreme low radial growth. Beech was more stable in radial growth. Spruce was more resistant to air pollution and climatic stress in mixed stands. Low temperature was limiting factor of radial growth together with climate extremes (such as strong frosts and more frequent droughts) and biotic factors (bark beetle, beech scale). Close-to-nature management supporting admixed tree species should lead in future to diversification of stand structure toward higher species, spatial and age structure to mitigate negative effect of climatic change.
\end{abstract}

Key words: natural regeneration; forest transformation; stand structure; forest dynamics; air pollution; Czech Republic

Editor: Bohdan Konôpka

\section{Introduction}

Pure and mixed forest stands of European beech (Fagus sylvatica $\mathrm{L}$.) were the most widespread forests in the Middle Age in Europe (Packham et al. 2012). In the course of centuries intensive forest management has changed their original species composition and stand structure in many localities (von Oheimb 2005; Petritan et al. 2015). For example in the Czech Republic, beech was represented by $40.2 \%$ in natural forests, currently it is represented by 8.4\% (MZe 2018). Forests of the temperate zone have usually undergone greater changes than other forest ecosystems (Terek \& Dobrovic 2013). In Central Europe, natural forest ecosystems were mostly affected and constrained by unfavourable anthropogenic factors (Jantsch et al. 2013; Bošel'a et al. 2016) as a result of dense human population (Barna \& Bosela 2015). In Central Europe, due to anthropic impacts, spruce monocultures take up a large portion of forest land (Spiecker et al. 2004). These stands have been repeatedly affected by disturbances in the last decades (Hlásny \& Sitková 2010; Briner et al. 2013) and consequently their long-term sustainability is questioned (Grodzki 2010).

Currently, crucial factors influencing forest ecosystems in Central Europe are climate extremes (winter desiccation, summer drought, wind storm), pollutants $\left(\mathrm{SO}_{2}\right.$, $\mathrm{NO}_{x}, \mathrm{O}_{3}$ ), bark beetle disturbances, excessive damage by ungulates (browsing, bark stripping) or inappropriate management (Flechard et al. 2011; Krejčí et al. 2013; Vacek et al. 2017a; Putalová et al. 2019). As in the last

*Corresponding author.Zdeněk Vacek, e-mail:vacekz@fld.czu.cz 
years gradual changes have occurred in forest management approaches in Central Europe, there has been a shift from the preference of coniferous monocultures to the support of mixed stands, natural regeneration and broadleaved species in general (Petritan et al. 2009; Slanař et al. 2017). Close-to-nature and sustainable forestry management practices have been increasingly applied (FAO 2006; Barbati et al. 2014). These alternative management strategies usually avoid a clear-cutting system while small-scale management and creation of mixed and structurally diversified forest stands is preferred (Schütz 1999; Tesař et al. 2004; Puettmann et al. 2015). Increasing the proportion of deciduous tree species and optimizing age and spatial composition of forest stands follows these management objectives and is therefore one of the key objectives of the modern forestry (Schütz 2002; Bílek et al. 2011; Puettmann et al. 2015). Target trees should be composed of at least $30 \%$ share of the original tree species composition and its close-to-nature structure differentiation is recommended (Poleno et al. 2009). This trend is also a result of recent conferences on forest conservation in Europe (MCPFE 2015) and at the same time it has become a dominant forestry paradigm in many countries (Butler \& Koontz 2005). The application of these modern principles should lead to an increase in stand resistance to disturbances and to an improvement in the ability of individual trees to survive (Jönsson et al. 2012; Neuner et al. 2014; Vacek et al. 2015). This is particularly important in areas with increasing extent of forest disturbances (Hlásny et al. 2017). Taking into account this trend, foresters try to reduce a difference in structural variability between natural and commercial forests and to establish a balance between ecological and socioeconomic functions of forest (Cardinall et al. 2004; Urli et al. 2017). In this context Vacek et al. (2014b) and Remeš et al. (2015) state that the stands that would undergo the process of transformation toward close-to-nature forests would fulfil ecological, environmental and socioeconomic functions of forest in a substantially better way.

European beech as one of the most important broadleaved species in Europe (Packham et al. 2012; Chianucci et al.2016) plays a crucial role in this trend of sustainable forest management (Bolte et al. 2007; Barna \& Bosela 2015). It is very important from both economic (Shahverdi et al. 2013) and ecological aspects (Drobyshev et al. 2014). In Central Europe, beech represents a potentially dominant species of natural vegetation in humid to moderately dry areas of submontane zones under current climatic conditions (Ellenberg 1996). Nevertheless, the expected climate changes (Lorz et al. 2010; Bilela et al. 2012; Machar et al. 2017) can worsen its vitality and competitiveness (Fotelli et al. 2003). The expected regional warming and the related decreasing water availability are considered as a significant negative factor with an impact on vitality and productivity of forest ecosystems in Central Europe (IPCC 2007). On the other hand, beech is a relatively resistant tree species, especially at the centre of its distribution range, with regard to global climate change (Bolte et al. 2010; Bošel'a et al. 2016; Králíček et al. 2017). Králíček et al. (2017) or Kolář et al. (2017) concluded that European beech show higher stability and resistance in relation to climate changes (especially to droughts) compared to Norway spruce. Nevertheless, Gessler et al. (2007) showed also potential risks for this tree species in relation to climate change. Close-to-nature management strategies should solve both ecological risks and related economic risks (Seidl et al. 2014; Schelhaas et al. 2015).

The purpose of present paper is to assess the possibilities of stabilization of spruce monocultures in the process of their transformation by gradual increase of beech and structural differentiation of the forest stands in Jizerské hory Mts. For the research, mixed (spruce-beech) forest stands were selected with different proportions of beech at the initial stage of the transformation, focusing on the area where the beech is the only one prospective ameliorating and stabilising tree species in relation to ungulate browsing and climatic change. The study evaluates the structure and dynamics of spruce-beech forest stands in the 40-year transformation phase toward close-to-nature structure with emphasis on production, ecological stability and biodiversity under ongoing global climate change. The main objectives were:

- to define production parameters, structure and biodiversity (vertical, horizontal, species and complex) of forest stands at the initial stage of forest transformation including dead wood characteristics,

- to quantify dynamics of diameter increment and resistance of European beech and Norway spruce on air pollution $\left(\mathrm{SO}_{2}, \mathrm{NO}_{\mathrm{X}}, \mathrm{O}_{3}\right)$, climatic factors (temperature, precipitation) and climate change,

- to estimate relationship among radial growth, tree species composition, climate and air pollution load in relation to forest stability,

- to quantify changes in structural diversity and species composition of natural regeneration compared to mature stand and the role of game damage in the process of transformation.

\section{Materials and methods}

\subsection{Study area}

The research was conducted on four permanent research plots (PRP) in the Jedlový důl area in the Protected Landscape Area Jizerské hory Mts. and Bird Conservation Area CZ0511008 Jizerské hory Mts., northern part of the Czech Republic (Fig. 1). The bedrock is composed of porphyritic medium-grained granite and granodiorite. Prevailing soil is Cambisols and Cryptopodzols (Vacek et al. 2003). 


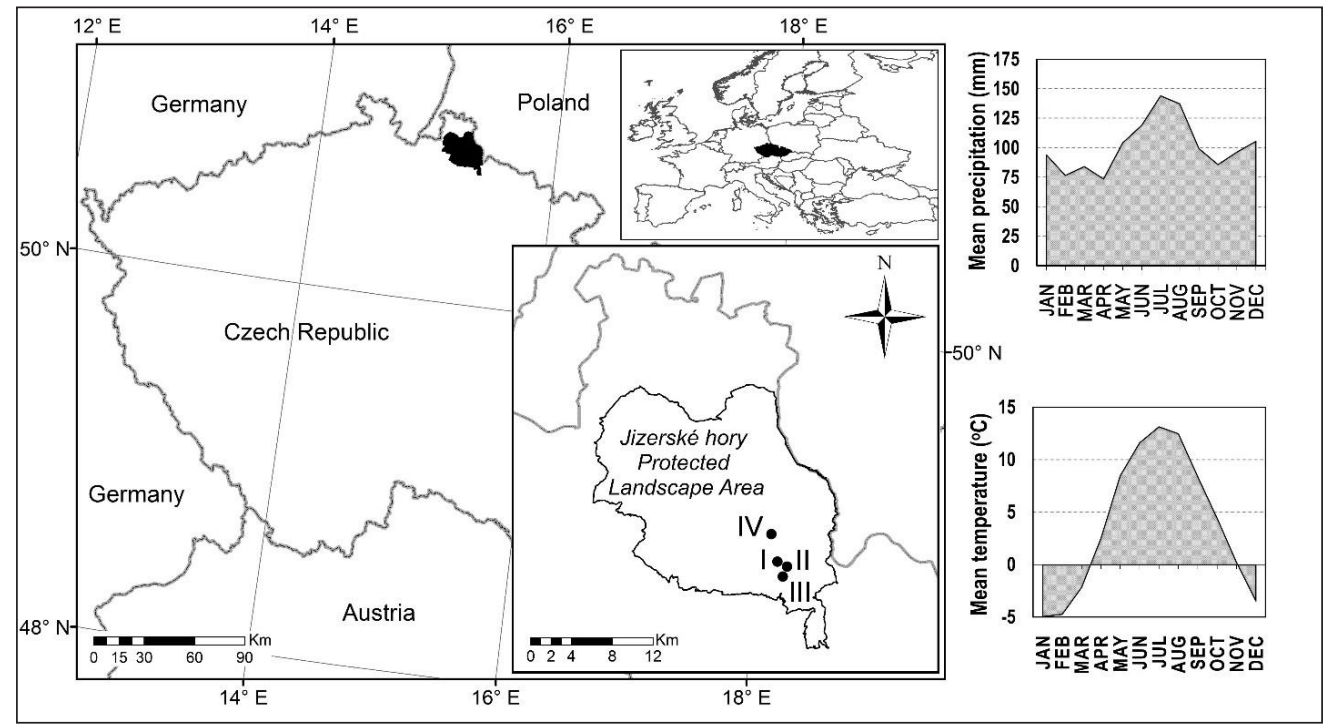

Fig. 1. The localization of spruce-beech forest stands on permanent research plots I - IV in the Jizerské hory Mts. with climatic characteristics (1960-2016).

The mean annual temperature was around $3.8^{\circ} \mathrm{C}$ and the mean annual sum of precipitation reached $1220 \mathrm{~mm}$ with minimum temperature in January $\left(-5.0^{\circ} \mathrm{C}\right)$, resp. precipitation in April (73 $\mathrm{mm})$ and maximum in July $(13.1$ ${ }^{\circ} \mathrm{C}, 144 \mathrm{~mm}$ ) in 1960-2016 (Fig. 1). During this period, the sum of precipitation average decreased by $77 \mathrm{~mm}$ and temperature increased by $1.8^{\circ} \mathrm{C}$ under climate change. On all PRP the growing season lasts for about 131 days, average temperature in the growing season was around $10.7^{\circ} \mathrm{C}$ with sum of precipitation $646 \mathrm{~mm}$. The study territory belongs to humid continental climate characterised by hot and humid summers and cold to severely cold winters (classification symbol Dfb) according to Köppen climate classification (Köppen 1936).

From the aspect of environmental pollution, $\mathrm{SO}_{2}$ concentrations had increased since 1970s in connection with the operation of large coal firing power station Turów in Poland (Vacek et al. 2003). The quantity of emissions increased there more than ten times in the course of two decades (45,000 tons of $\mathrm{SO}_{2}$ in 1957, 500,000 tons of $\mathrm{SO}_{2}$ in 1980) - (Jirgle et al. 1983). Currently, a substantial decrease in $\mathrm{SO}_{2}$ concentrations from 28 to $3 \mu \mathrm{g} \mathrm{m}^{-3}$ was reached since 1972. Average concentrations of $\mathrm{NO}_{\mathrm{x}}$ are around $7 \mu \mathrm{g} \mathrm{m}^{-3}$ and the $\mathrm{O}_{3}$ exposure index AOT40F is $27,000 \mathrm{ppb} \mathrm{h}^{-1}$.
The studied territory is covered by spruce-beech forests with individual admixture of sycamore maple (Acer pseudoplatanus L.), silver fir (Abies alba Mill.), rowan (Sorbus aucuparia L.) and silver birch (Betula pendula Roth; Table 1). Silver fir was introduced into these stands in the $80 \mathrm{~s}$ and $90 \mathrm{~s}$ of the $20^{\text {th }}$ century through group underplantings. At the end of the 1970s and during the 1980s in connection with the air pollution load, gradual release of suppressed beech trees started in declining spruce forest stands. Substantial care for the mature beech crowns contributed to their future fertility and natural regeneration. These silviculture practises have begun the initial transformation of spruce stands in study area of the Jizerské hory Mts. (Vacek \& Cipra 1979). On PRP forest transformation based on the principles of shelterwood and selection system has been applied since 2000. In terms of phytocoenology PRP belong to acidophilous beech forests (the association Luzulo-luzuloidisFagetum sylvaticae Meusel 1937, Calamagrostio villosaeFagetum Mikyška 1972) and partly forms of herb-rich beech forests (the association Dentario enneaphylliFagetum Oberdorfer ex W. et A. Matuszkiewicz 1960).

Table 1. Basic site and stand characteristics of permanent research plots I, II, III and IV according to forest management plan.

\begin{tabular}{|c|c|c|c|c|c|c|c|c|}
\hline PRP & GPS coordinates & $\begin{array}{c}\text { Altitude } \\
{[\mathrm{m}]}\end{array}$ & Exposition & $\begin{array}{c}\text { Slope } \\
\left.{ }^{\circ}\right]\end{array}$ & Forest site type $\mathrm{e}^{1}$ & Tree species & $\begin{array}{l}\text { Age } \\
\text { [y] }\end{array}$ & $\begin{array}{c}\text { Stand volume } \\
{\left[\mathrm{m}^{3} \mathrm{ha}^{-1}\right]}\end{array}$ \\
\hline I & $\begin{array}{l}50^{\circ} 46^{\prime} 53^{\prime \prime} \mathrm{N} \\
15^{\circ} 15^{\prime} 15^{\prime \prime} \mathrm{E}\end{array}$ & 715 & SW & 12 & $6 \mathrm{~S}$ & FS, PA, BP & $129 / 12$ & 438 \\
\hline II & $\begin{array}{l}50^{\circ} 46^{\prime} 42^{\prime \prime} \mathrm{N} \\
15^{\circ} 15^{\prime} 46^{\prime \prime} \mathrm{E}\end{array}$ & 730 & $\mathrm{SE}$ & 15 & $6 \mathrm{~S}(6 \mathrm{~A})$ & FS, PA & $166 / 12$ & 512 \\
\hline III & $\begin{array}{l}50^{\circ} 46^{\prime} 28^{\prime \prime} \mathrm{N} \\
15^{\circ} 15^{\prime} 40^{\prime \prime} \mathrm{E}\end{array}$ & 640 & SE & 22 & $6 \mathrm{~S}(6 \mathrm{~A})$ & FS, PA, SA, & $164 / 12$ & 532 \\
\hline IV & $\begin{array}{l}50^{\circ} 47^{\prime} 48^{\prime \prime} \mathrm{N} \\
15^{\circ} 15^{\prime} 41^{\prime \prime} \mathrm{E}\end{array}$ & 810 & SE & 15 & $6 \mathrm{~S}$ & FS, PA, AA, AP & $168 / 12$ & 327 \\
\hline
\end{tabular}

Notes: ${ }^{1} 6 \mathrm{~S}$ - Piceo-Fagetum oligomesotrophicum represent vegetation associations of Calamagrostio villosae-Fagetum Mikyška 1972, 6A-Aceri-Piceeto-Fagetum lapidosum represent vegetation associations of Aceri-Fagetum J. et M. Bartsch 1940; tree species FS - Fagus sylvatica, PA - Picea abies, AA - Abies alba, SA - Sorbus aucuparia, AP - Acer pseudoplatanus, BP - Betula pendula. 


\subsection{Data collection}

FieldMap technology (IFER-Monitoring and Mapping Solutions Ltd.) was used to determine the structure of the tree layer, dead wood and natural regeneration in 2015-2016 on four PRP of $50 \times 50 \mathrm{~m}$ in size. The position of all individuals of the tree layer with diameter at breast height $(\mathrm{DBH}) \geq 4 \mathrm{~cm}$ and crown projections were localized, minimally at 4 directions perpendicular to each other. DBH of the tree layer were measured with a metal calliper (accuracy $1 \mathrm{~mm}$ ) and tree heights and heights of live crown base were measured with a Vertex laser hypsometer (accuracy 0.1 m; Haglöf, Sweden).

In 15 dominant and co-dominant trees of each main tree species (spruce and beech) on each PRP (only spruce on PRP 3), increment sample cores at DBH $(130 \mathrm{~cm})$ perpendicular to the axis of the tree along the slope and against the slope were taken by the Pressler's borer. Annual ring widths were measured with an Olympus binocular magnifier (accuracy $0.01 \mathrm{~mm}$ ) on the LINTAB measuring table (Rinntech) and recorded by TSAPWIN (Registograph).

For naturally regenerated individuals with DBH $<4 \mathrm{~cm}$ and height $\geq 150 \mathrm{~cm}$ these characteristics were measured on the whole PRP: position, height, height of live crown base, crown width (with a height measuring pole to the $1 \mathrm{~cm}$ ) and damage by ungulate (branch browsing, bark stripping). For standing and lying dead wood (diameter $\geq 7 \mathrm{~cm}$, length $\geq 1 \mathrm{~m}$ ) the position, tree species and volume according to the Harmon et al. (1986) method were determined.

\subsection{Data analysis}

Based on measured dendrometric data of tree layer, stand volume (Petráš \& Pajtík 1991), stocking (stand density index - SDI) and canopy density (crown closure and crown projection area) were computed. For natural regeneration and tree layer species diversity by the following indices were evaluated: species richness $D$ (Margalef 1958), species heterogeneity $H^{\prime}$ (Shannon 1948) and species evenness $E$ (Pielou 1975). Structural and total diversity was evaluated by Arten-profile index $A$ (Pretzsch 2006), diameter $T M_{d}$ and height $T M_{h}$ dif- ferentiation index (Füldner 1995), index of non-randomness $\alpha$ (Mountford 1961), aggregation index $R$ (Clark \& Evans 1954) and total diversity index $B$ (Jaehne \& Dohrenbusch 1997) using the software Sibyla (Fabrika \& Durský 2005). Ten criteria were implemented in order to characterize forest status (Table 2).

Characteristics describing the horizontal structure of individuals within the plot were calculated using software PointPro 2.2 (Zahradník \& Puš 2010). The test of significance of differences from values expected for the random layout of points was carried out by Monte Carlo simulations. Mean values of the $L$-function were estimated as means of $L$-functions calculated for 1999 randomly generated point structures. The spatial relations of natural regeneration and tree layer were evaluated by the cross-type pair correlation function $G(r)$ using software R (R Project). Layout maps were created in the ArcGIS (Esri).

The annual rings series were individually cross-dated (error correction of missing rings) using statistical tests in the PAST application program (SCIEM) and, subsequently, subjected to visual inspection by Yamaguchi (1991). If a missing annual ring was found, a ring of $0.01 \mathrm{~mm}$ was inserted in its place. Individual curves from a PRP were age detrended by the 100 years spline and used to create the average annual-ring series in the ARSTAN program (Laboratory of Tree-Ring Research). Negative significant pointer years were analyzed for each tree and subsequently for all PRP and tree species according to Schwein-Gruber et al. (1990). These pointer years were tested as an extremely narrow annual ring reaching less than $40 \%$ of the mean diameter increment of tree in 4 preceding years. It was proven if such a strong reduction in radial growth occurred in at least $20 \%$ of the trees on the plot. Average annual ring series of the PRP were correlated with climatic data (precipitation, temperatures 1961-2015 from Bedřichov Station-777 a.s.l.) and with air pollution data $\left(\mathrm{SO}_{2}\right.$ 1975-2015, $\mathrm{NO}_{\mathrm{x}}$ 1992-2012 and AOT40F 1996-2012 from Desná-Souš Station 772 a.s.l.). Both stations are located in the Jizerské hory Mts. within an 8-km range of the PRP. DendroClim software (DedroLab) was used to model the diameter increment in relation to climatic characteristics.

Table 2. Overview of indices describing the stand diversity and their common interpretation.

\begin{tabular}{|c|c|c|c|c|}
\hline Criterion & Quantifiers & Label & Reference & Evaluation \\
\hline \multirow{3}{*}{ Species diversity } & Richness & $D$ (Mai) & Margalef (1958) & minimum $\mathrm{D}=0$, higher $\mathrm{D}=$ higher values \\
\hline & Heterogeneity & $H^{\prime}(\mathrm{Si})$ & Shannon (1948) & minimum $\mathrm{H}^{\prime}=0$, higher $\mathrm{H}^{\prime}=$ higher values \\
\hline & Evenness & $E$ (Pii) & Pielou (1975) & range $0-1 ;$ minimum $E=0$, maximum $E=1$ \\
\hline Vertical diversity & Arten-profile index & $A$ (Pri) & Pretzsch (2006) & $\begin{array}{c}\text { range } 0-1 \text {; balanced vertical structure } A<0.3 ; \\
\text { selection forest } A>0.9\end{array}$ \\
\hline Structure differentiation & $\begin{array}{l}\text { Diameter dif. } \\
\text { Height dif. }\end{array}$ & $\begin{array}{l}T M_{d}(\mathrm{Fi}) \\
T M_{b}(\mathrm{Fi})\end{array}$ & Füldner (1995) & range $0-1$; low TM $<0.3$; very high differentiation $\mathrm{TM}>0.7$ \\
\hline \multirow{3}{*}{ Horizontal structure } & Index of non-randomness & $\alpha(\mathrm{P} \& \mathrm{Mi})$ & Mountford (1961) & mean value $\alpha=1$; aggregation $\alpha>1$; regularity $\alpha<1$ \\
\hline & Aggregation index & $R(\mathrm{C} \& \mathrm{Ei})$ & Clark \& Evans (1954) & mean value $R=1$; aggregation $R<1$; regularity $R>1$ \\
\hline & Index of cluster size & CSI(D\&Mi) & David \& Moore (1954) & mean value ICS $=0$; aggregation ICS $>0$; regularity ICS $<1$ \\
\hline Complex diversity & Stand diversity & $B(J \& D i)$ & Jaehne \& Dohrenbusch (1997) & $\begin{array}{c}\text { monotonous structure } \mathrm{B}<4 \text {; uneven structure } \mathrm{B}=6-8 \text {; very diverse } \\
\text { structure } \mathrm{B}>9\end{array}$ \\
\hline
\end{tabular}


Statistical analyses were processed in the Statistica 12 (StatSoft, Tulsa). Radial growth dataset with air pollution and climatic factors were tested by the Pearson correlation coefficient. Unconstrained principal component analysis (PCA) in Canoco 5 (Šmilauer \& Lepš 2014) was used to analyse relationships between growth of beech and spruce on PRP, climate factors and air pollution data in 1975-2015. Data were log-transformed, centred and standardized before the analysis.

\section{Results}

\subsection{Production parameters and structure of tree layer}

Tree density ranged from 272 to 416 trees ha $^{-1}$ (in European beech $40-212$ trees ha $^{-1}$ and in Norway spruce 10 328 trees ha $^{-1}$ ) with SDI $0.51-0.74$ (Table 3 ). The stand volume reached $441-731 \mathrm{~m}^{3} \mathrm{ha}^{-1}$, while beech accounted for $0-544 \mathrm{~m}^{3} \mathrm{ha}^{-1}$ and spruce for $166-442 \mathrm{~m}^{3} \mathrm{ha}^{-1}$. The highest stand volume $\left(731 \mathrm{~m}^{3} \mathrm{ha}^{-1}\right)$ was found out on
PRP III, and the lowest on PRP I $\left(441 \mathrm{~m}^{3} \mathrm{ha}^{-1}\right)$. Sprucebeech stands had dominant representation of Norway spruce on PRPI, II and III (60.7-99.9\%), only on PRPIV European beech was dominant tree species $(76.8 \%)$. The basal area was in the range of $36.0-50.4 \mathrm{~m}^{2} \mathrm{ha}^{-1}$ (in beech $0.1-34.9 \mathrm{~m}^{2} \mathrm{ha}^{-1}$ and in spruce $13.0-35.9 \mathrm{~m}^{2} \mathrm{ha}^{-1}$ ). Periodic annual increment of stands ranged from 5.0 to $7.0 \mathrm{~m}^{3} \mathrm{ha}^{-1} \mathrm{y}^{-1}$ and mean annual increment was $3.4-$ $4.5 \mathrm{~m}^{3} \mathrm{ha}^{-1} \mathrm{y}^{-1}$. Canopy closure was $57.6-92.0 \%$ and crown projection area ranged between 0.86 and 2.52 (Table 3).

Spruce-beech stands on PRP were two or three-storeyed stands. The trees on PRP reached the mean DBH of $35.3-45.1 \mathrm{~cm}$, in beech it was $6.0-45.8 \mathrm{~cm}$ and in spruce $37.3-50.2 \mathrm{~cm}$. On PRP I, III and IV the occurrence of diameter classes $32-36$ and $36-40 \mathrm{~cm}$ was the highest, only on PRP II the class $>56 \mathrm{~cm}$ was prevailing (Fig. 2). On PRP I-III beech prevailed in the small classes while on PRP IV it was spruce. The tallest individuals of beech and spruce on PRP reached the height of $33-37 \mathrm{~m}$ and $38-43 \mathrm{~m}$, respectively. The heights of live crown base were highly variable both in beech and spruce. In the

Table 3. Stand characteristics of spruce-beech stands on permanent research plots in 2016.

\begin{tabular}{|c|c|c|c|c|c|c|c|c|c|c|c|c|c|}
\hline PRP & Species & $\begin{array}{l}\text { Age } \\
\text { [y] }\end{array}$ & $\begin{array}{l}\mathrm{dbh} \\
{[\mathrm{cm}]}\end{array}$ & $\begin{array}{c}\mathrm{h} \\
{[\mathrm{m}]}\end{array}$ & $\begin{array}{c}\mathrm{v} \\
{\left[\mathrm{m}^{3}\right]}\end{array}$ & $\begin{array}{c}\mathrm{N} \\
\text { [trees ha }^{-1} \text { ] }\end{array}$ & $\begin{array}{c}\text { BA } \\
\left\lceil\mathrm{m}^{2} \mathrm{ha}^{-1}\right\rceil\end{array}$ & $\begin{array}{c}\mathrm{V} \\
\left\lceil\mathrm{m}^{3} \mathrm{ha}^{-1}\right\rceil\end{array}$ & $\begin{array}{c}\text { PAI } \\
{\left[\mathrm{m}^{3} \mathrm{ha}^{-1} \mathrm{y}^{-1}\right\rceil}\end{array}$ & $\begin{array}{c}\text { MAI } \\
{\left[\mathrm{m}^{3} \mathrm{ha}^{-1} \mathrm{y}^{-1}\right\rceil}\end{array}$ & $\begin{array}{l}\mathrm{CC} \\
{[\%]}\end{array}$ & $\begin{array}{l}\text { CPA } \\
\text { [ha] }\end{array}$ & SDI \\
\hline \multirow{3}{*}{ I } & Spruce & 130 & 37.3 & 29.8 & 1.345 & 328 & 35.9 & 441 & 5.0 & 3.39 & 55.2 & 0.80 & 0.51 \\
\hline & Beech & 16 & 6.0 & 5.3 & 0.003 & 40 & 0.1 & 0 & 0.0 & 0.00 & 5.3 & 0.05 & 0.00 \\
\hline & Total & 130 & 35.3 & 27.1 & 1.199 & 368 & 36.0 & 441 & 5.0 & 3.39 & 57.6 & 0.86 & 0.51 \\
\hline \multirow{3}{*}{ II } & Spruce & 160 & 50.2 & 34.0 & 2.765 & 160 & 31.6 & 442 & 3.9 & 2.76 & 59.8 & 0.91 & 0.40 \\
\hline & Beech & 164 & 36.8 & 22.5 & 1.637 & 112 & 11.8 & 183 & 2.0 & 1.12 & 63.0 & 1.00 & 0.20 \\
\hline & Total & 161 & 45.1 & 29.2 & 2.301 & 272 & 43.4 & 626 & 6.0 & 3.89 & 85.1 & 1.91 & 0.60 \\
\hline \multirow{3}{*}{ III } & Spruce & 165 & 39.0 & 32.6 & 1.626 & 272 & 32.4 & 442 & 4.1 & 2.68 & 67.1 & 1.11 & 0.45 \\
\hline & Beech & 160 & 40.0 & 25.7 & 2.002 & 144 & 18.0 & 288 & 2.9 & 1.80 & 75.5 & 1.41 & 0.29 \\
\hline & Total & 163 & 39.3 & 30.2 & 1.756 & 416 & 50.4 & 731 & 7.0 & 4.48 & 92.0 & 2.52 & 0.74 \\
\hline \multirow{3}{*}{ IV } & Spruce & 162 & 39.4 & 25.9 & 1.537 & 108 & 13.0 & 166 & 1.6 & 1.02 & 26.1 & 0.30 & 0.18 \\
\hline & Beech & 161 & 45.8 & 32.1 & 2.568 & 212 & 34.9 & 544 & 5.1 & 3.38 & 80.8 & 1.65 & 0.53 \\
\hline & Total & 161 & 43.7 & 30.0 & 2.220 & 320 & 48.0 & 710 & 6.7 & 4.41 & 85.9 & 1.96 & 0.72 \\
\hline
\end{tabular}

Notes: Age - average stand age; dbh - mean quadratic breast height diameter; $\mathrm{h}$ - mean height; $\mathrm{v}$ - average tree volume; $\mathrm{N}$ - number of trees; BA-basal area; $\mathrm{V}$ - stand volume; PAI - periodic annual increment; MAI - mean annual increment, CC - canopy closure, CPA - crown projection area, SDI - stand density index.

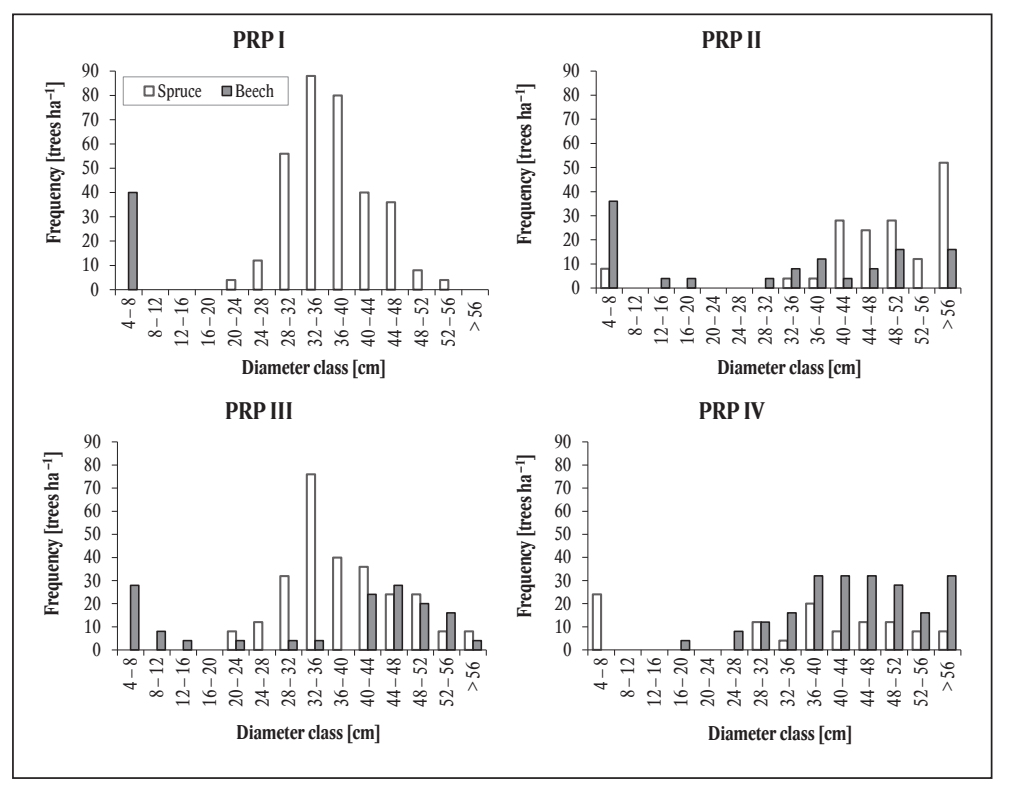

Fig. 2. Histogram of diameter classes by main tree species in a mixed stands on permanent research plots in 2016. 
understorey it was mostly $1-3 \mathrm{~m}$ and in the overstorey $7-19 \mathrm{~m}$.

The occurrence of dead wood ranged from 4.3 to $31.8 \mathrm{~m}^{3} \mathrm{ha}^{-1}$ (on average $16.4 \mathrm{~m}^{3} \mathrm{ha}^{-1}$ ). The volume of lying dead wood was $0.0-18.2 \mathrm{~m}^{3} \mathrm{ha}^{-1}$ and standing dead wood was in range $2.7-22.6 \mathrm{~m}^{3} \mathrm{ha}^{-1}$. Comparing total stand volume on PRP, volume of dead wood (lying DW $30.2 \%$, standing DW $69.8 \%$ ) formed $2.6 \%$ and stand volume of living trees $97.4 \%$.

\subsection{Biodiversity of tree layer}

Vertical structure according to the Arten-profile index $A$ was medium to highly diversified $(0.395-0.725$; Table 4). Diameter differentiation $T M_{d}$ was low to medium $(0.238-0.375)$, such as height differentiation $T M_{h}$ $(0.180-0.341)$. Species richness $D$ was low $(0.166-$
0.178). Species heterogeneity expressed by entropy $H^{\prime}$ indicated minimum to low biodiversity $(0.009-0.283)$. According to species evenness $E$, biodiversity on PRP I was low (0.030) while biodiversity on the other PRP was very high $(0.844-0.944)$. Total diversity according $B$ indicated even structure on PRP IV (5.909) and uneven structure on the other PRP $(6.219-6.457)$.

Horizontal structure of the tree layer of mixed stands with dominant representation of European beech and Norway spruce was regular on all PRP (significantly according to $R$ and $C S$ indices; Table 4, Fig. 3). Conversely the mostly random pattern of tree layer individuals according to their distance (spacing) was indicated by Ripley's $L$-function. Regular horizontal structure was observed on PRP at small spacing in distance from tree stem to $3-4 \mathrm{~m}$.

Table 4. Stand biodiversity indices of mixed stands on permanent research plots in 2016.

\begin{tabular}{lcccccccccc}
\hline PRP & D (Mai) & $\mathrm{H}^{\prime}(\mathrm{Si})$ & $\mathrm{E}(\mathrm{Pii})$ & $\mathrm{A}(\mathrm{Pri})$ & $\mathrm{TM}_{\mathrm{d}}(\mathrm{Fi})$ & $\mathrm{TM}_{\mathrm{b}}$ (Fi) & $\alpha(\mathrm{P} \& \mathrm{Mi})$ & $\mathrm{R}(\mathrm{C} \& \mathrm{Ei})$ & $\mathrm{CS}(\mathrm{D} \& \mathrm{Mi})$ & $\mathrm{B}(\mathrm{J} \& \mathrm{Di})$ \\
\hline I & 0.169 & 0.009 & 0.030 & 0.395 & 0.238 & 0.188 & $0.802^{*}$ & $1.245^{*}$ & $-0.421^{*}$ & 6.219 \\
II & 0.178 & 0.254 & 0.844 & 0.664 & 0.375 & 0.341 & 0.816 & $1.228^{*}$ & $-0.259^{*}$ & 6.295 \\
III & 0.166 & 0.283 & 0.940 & 0.725 & 0.306 & 0.204 & 0.995 & $1.265^{*}$ & $-0.344^{*}$ & 6.457 \\
IV & 0.173 & 0.254 & 0.844 & 0.512 & 0.310 & 0.180 & 0.929 & $1.274^{*}$ & $-0.343^{*}$ & 5.909 \\
\hline
\end{tabular}

Notes: D - species richness index; $\mathrm{H}^{\prime}$ - species heterogeneity index (entropy); $\mathrm{E}$ - species evenness index; $\mathrm{A}$-Arten-profile index; $\mathrm{TM}_{\mathrm{d}}$ - diameter differentiation index, $\mathrm{TM}_{\mathrm{h}}$ - height differentiation index, $\alpha$-index of non-randomness, $\mathrm{R}$ - aggregation index, CS - index of cluster size, $\mathrm{B}$ - total diversity index.

* statistically significant $(\mathrm{p}>0.05)$ for horizontal structure (in all cases regularity).

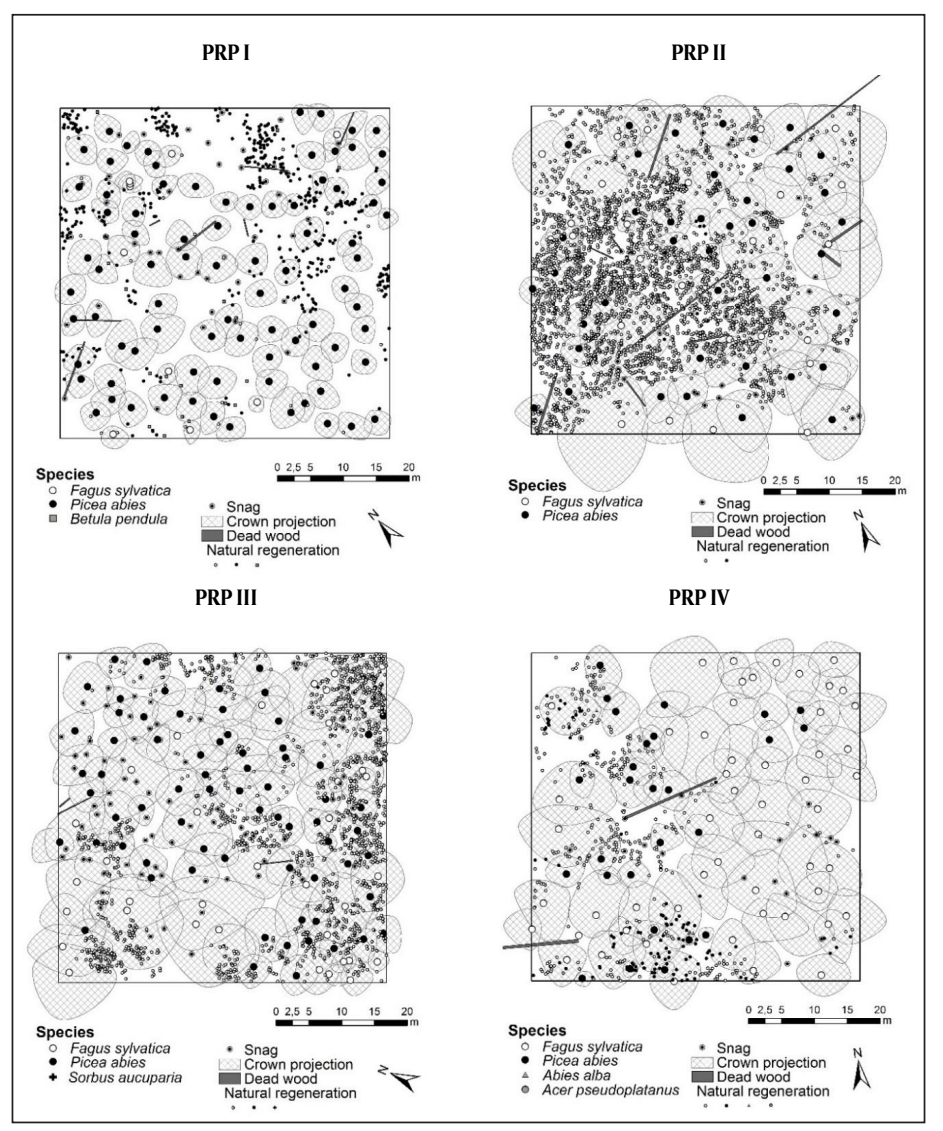

Fig. 3. Horizontal structure of mixed stands on permanent research plots in 2016. 


\subsection{Radial growth of European beech and Norway spruce}

Dynamics of Norway spruce showed very strong growth depression in 1979-1987 with pronounced minimum growth in 1980-1982 that was caused by an interaction of air pollutants $\left(\mathrm{SO}_{2}\right)$, climate stress and bark beetle feeding (Fig. 4). This trend was not observed on PRP 8 where spruce is only admixed tree species. In spruce, years 1980, 1981, 1982 and 2004 were observed as the strong incidence of beech scale (Cryptococcus fagi). In beech, years 1997 and 2012 were observed as the negative pointer years with extreme low radial growth (Fig. 4). Higher balance of radial growth was manifested in beech $(\mathrm{SD} \pm 0.14)$ compared to spruce $(\mathrm{SD} \pm 0.22)$. Average diameter increment of spruce on PRP I, II, III and IV in 1960-2015 was in positive correlation with temperatures in April of the preceding year and current year ( $\mathrm{r}$ $=0.26-0.22$ ). Besides, radial growth showed a positive correlation with rainfall in May of the preceding year ( $\mathrm{r}$

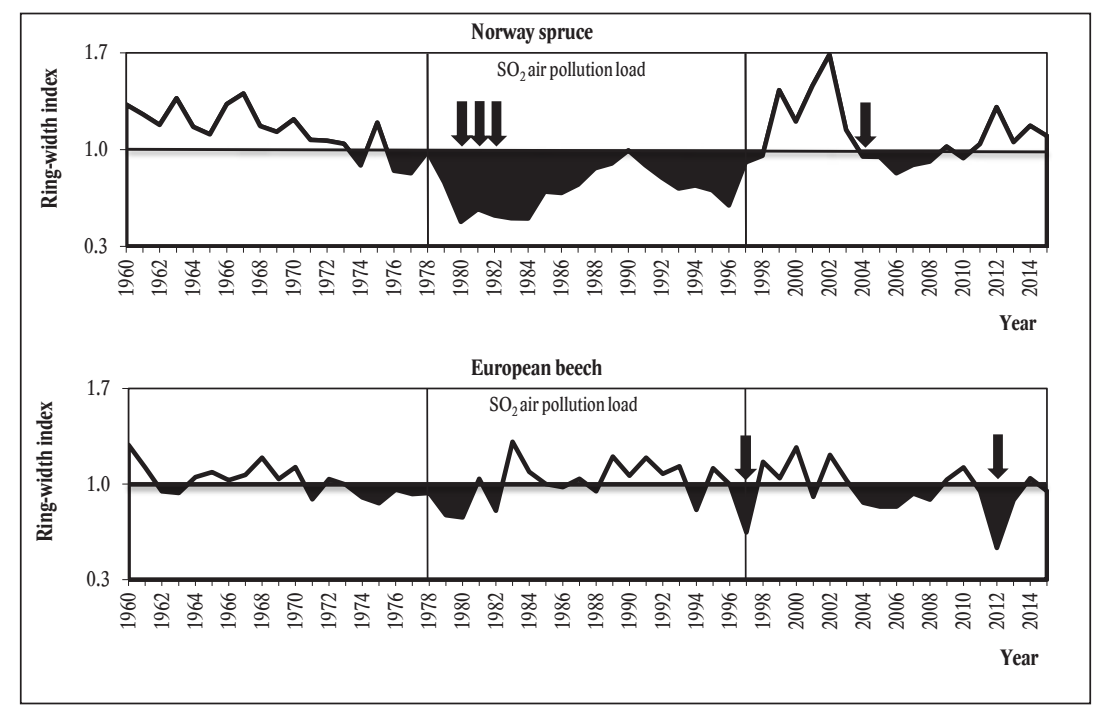

Fig. 4. Standardized mean chronology of Norway spruce and European beech in 1960-2015 expressed by the tree ring index (in 1960 used $100 \%$ of tree cores; the oldest tree rings dated back to 1852); arrows indicate significant negative pointer years with extreme low radial growth reaching less than $40 \%$ of the mean diameter increment in previous 4 years and occurred in at least $20 \%$ of the trees.

negative pointer years with extreme low radial growth. Generally, the highest variability in ring-width index was observed on PRP I and II (SD \pm 0.25$)$ with the highest share of spruce, while the relatively balanced radial growth of spruce was observed on beech dominated PRP $\mathrm{IV}(\mathrm{SD} \pm 0.16)$.

Growth depressions of European beech on PRP II, III and IV was observed in 1979, 1980 and 1982 with pronounced minimum growth in 1980 that were caused by the synergism of air pollutants, climate extreme and
$=0.25)$ and a negative correlation with precipitation in November of the preceding year $(r=-0.23)$ and April of current year ( $r=-0.23$; Fig. 5).

Average diameter increment of beech on PRP II, III and IV in 1960-2015 was in positive correlation with temperatures in July and August of the preceding year $(r=0.33-0.22)$ and in April of the currentyear $(r=0.32)$. In addition, radial growth showed a positive correlation with precipitation in May of the current year $(r=0.23)$ and a negative correlation with precipitation in July of the

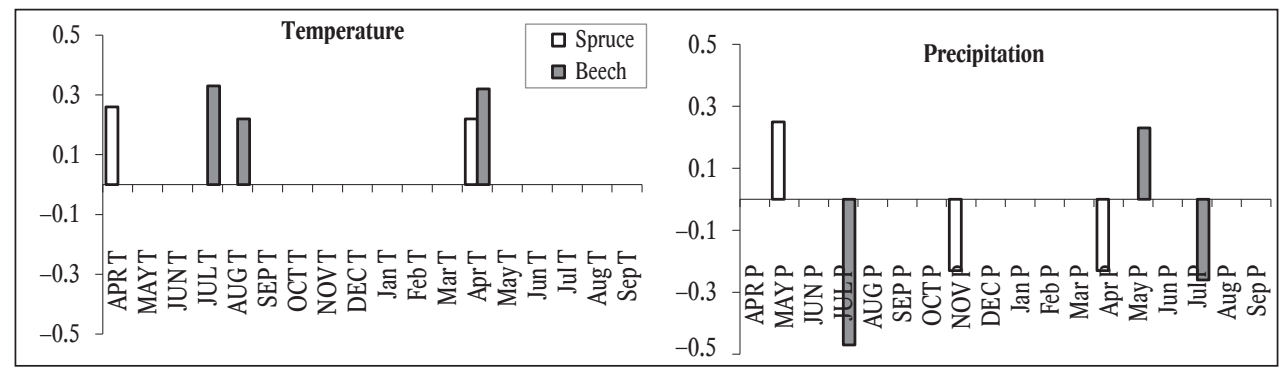

Fig. 5. Correlation coefficients of the regional residual tree-ring index chronology of Norway spruce and European beech with the monthly temperature (left) and precipitation (right) from April to December of the preceding years (capitals) and from January to September of the current year (lower case) summary for all permanent research plots in 1960-2015. Only correlation coefficients of statistically significant values are presented $(\alpha=0.05 \%)$. 


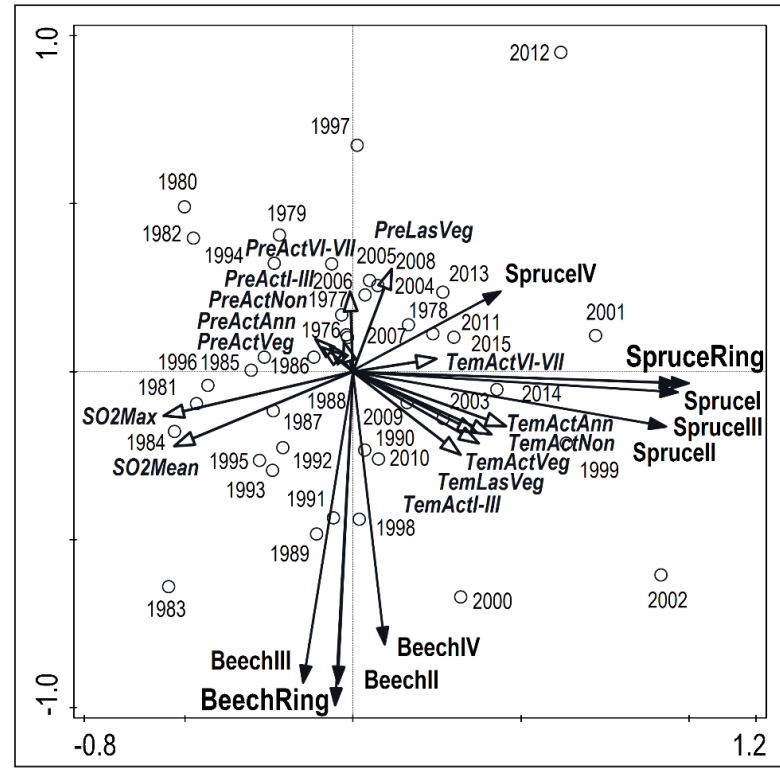

Fig. 6. Ordination diagram of PCA showing relationships between climate data (Tem - mean temperature, Pre - sum of precipitation, Act - current year, Las - preceding year, Veg - growing season, NonVeg - non-growing season, I-III, VI-VII - months), $\mathrm{SO}_{2}$ concentrations (mean - mean annual concentration, max - maximum concentration) and tree-ring width (Ring - mean tree-ring width) for beech and spruce on permanent research plots I, II, III and IV; codes $\mathrm{O}$ indicate years 1977-2015.

preceding year $(\mathrm{r}=-0.48)$ and current year $(\mathrm{r}=-0.26$; Fig. 5).

Interactions among radial growth of beech and spruce, climate factors and $\mathrm{SO}_{2}$ concentrations are presented in an ordination diagram of PCA (Fig. 6). The first ordination axis explains $43.2 \%$ of data variability, the first two axes together explain $82.2 \%$ and the first four axes $97.4 \%$. The $x$-axis illustrates the radial growth of spruce stands and the y-axis represents the radial growth of beech. $\mathrm{SO}_{2}$ concentrations (average and maximum ones) were negatively correlated with spruce radial growth while there was no effect on growth of beech. Spruce increment was in positive correlation with temperature, especially with average annual temperature and temperature in June and July of the current year. Beech increment was negatively correlation with precipitation. Overall, the effect of temperature on diameter increment was more significant in comparison with very low influence of precipitation. In the period of the $80 \mathrm{~s}$ and $90 \mathrm{~s}$ of the $20^{\text {th }}$ century the radial growth was affected especially by high $\mathrm{SO}_{2}$ concentrations while in the second half of the studied period (after 2000) there was a closer correlation between growth and air temperature.

The radial growth increment of spruce showed a significantly negative correlation with the mean annual and maximum daily $(\mathrm{r}=-0.53,-0.56 ; \mathrm{p}<0.001) \mathrm{SO}_{2}$ concentrations (Table 5). Specifically, the highest negative effect of $\mathrm{SO}_{2}$ concentrations was observed in July and February $(\mathrm{r}=-0.58,-0.51 ; \mathrm{p}<0.001)$. The lowest effect of $\mathrm{SO}_{2}$ was observed on PRP IV with dominant beech $(\mathrm{r}=-0.44, \mathrm{p}<0.01)$. Mean annual $\mathrm{NO}_{\mathrm{x}}$ concentrations had also negative effect on spruce increment $(\mathrm{r}=-0.43$; $p<0.05$ ). Ozone exposure had no effect on diameter increment of spruce. Spruce was significantly positively influenced by annual temperature and temperature in the growing season $(r=0.46,0.41 ; p<0.01)$, while the lowest non-significant effect was observed again on PRP IV $(p>0.05)$.

Generally, beech showed higher resistance to air pollutants load and was less influenced by summary climatic variables. $\mathrm{O}_{3}, \mathrm{NO}_{\mathrm{x}}$, and $\mathrm{SO}_{2}$ concentrations had no significant effect on radial growth of beech, such as temperature and precipitation during the year and in the growing season (Table 5).

\subsection{Structure and diversity of natural regeneration}

The number of natural regeneration (height $\geq 1.5 \mathrm{~m}$ ) on PRP ranged from 1,800 (PRP IV) to 13,356 (PRP II) recruits ha ${ }^{-1}$ (Table 6). Beech on PRP accounted for $7-100 \%$, spruce for $0-89 \%$, silver fir $0-1 \%$ and silver

Table 5. Correlation matrix describing interactions between the radial growth of spruce and beech, precipitation and temperature (1975-2015) and concentrations of $\mathrm{SO}_{2}$ (1975-2015), $\mathrm{NO}_{\mathrm{x}}$ (1992-2012) and AOT40F (1996-2012). Significant correlations are designated by * $(\mathrm{p}<0.05)$ and ** $(\mathrm{p}<0.01)$.

\begin{tabular}{lccccccccc}
\hline \multirow{2}{*}{ Ring width index } & $\mathrm{SO}_{2}$ & $\mathrm{SO}_{2}$ & $\mathrm{NO}_{\mathrm{x}}$ & $\mathrm{NO}_{\mathrm{x}}$ & \multirow{2}{*}{ AOT40F } & $\begin{array}{c}\text { Temp } \\
\text { ActAnn }\end{array}$ & $\begin{array}{c}\text { Temp } \\
\text { ActVeg }\end{array}$ \\
& mean & max. & mean & PctAnn & $\begin{array}{c}\text { Prec } \\
\text { ActVeg }\end{array}$ \\
\hline Beech stands & 0.22 & 0.14 & 0.07 & -0.03 & 0.22 & 0.14 & 0.15 & -0.09 & -0.04 \\
Spruce stands & $-0.53^{* *}$ & $-0.56^{* *}$ & $-0.43^{*}$ & -0.37 & -0.06 & $0.46^{* *}$ & $0.41^{* *}$ & -0.13 & -0.09 \\
\hline
\end{tabular}

Notes: $\mathrm{SO}_{2}\left(\mathrm{NO}_{\mathrm{Y}}\right)$ mean - mean annual $\mathrm{SO}_{2}\left(\mathrm{NO}_{\mathrm{x}}\right)$ concentration, $\mathrm{SO}_{2}\left(\mathrm{NO}_{\mathrm{X}}\right)$ max - maximum $\mathrm{SO}_{2}\left(\mathrm{NO}_{\mathrm{x}}\right)$ concentrations, AOT40F - ozone exposure, TempActAnn - mean annual temperature of the given year, TempActVeg - mean temperature in the growing season of the given year, PrecActAnn - annual sum of precipitation of given year, PrecActVeg - sum of precipitation in the growing season of the given year.

Table 6. Mean height of natural regeneration and its density per hectare from registration height of $1.5 \mathrm{~m}$ according to tree species.

\begin{tabular}{|c|c|c|c|c|c|c|c|c|c|c|c|c|c|c|}
\hline \multirow{2}{*}{ PRP } & \multicolumn{2}{|c|}{ Spruce } & \multicolumn{2}{|c|}{ Beech } & \multicolumn{2}{|c|}{ Fir } & \multicolumn{2}{|c|}{ Rowan } & \multicolumn{2}{|c|}{ Birch } & \multicolumn{2}{|c|}{ Sycamore } & \multicolumn{2}{|c|}{ Total } \\
\hline & [ind.] & {$[\mathrm{cm}]$} & [ind.] & {$[\mathrm{cm}]$} & [ind.] & {$[\mathrm{cm}]$} & [ind.] & {$[\mathrm{cm}]$} & [ind.] & {$[\mathrm{cm}]$} & [ind.] & {$[\mathrm{cm}]$} & [ind.] & {$[\mathrm{cm}]$} \\
\hline I & 1,608 & 190.0 & 120 & 262.0 & 0 & - & 0 & - & 72 & 285.8 & 0 & - & 1,800 & 198.6 \\
\hline II & 24 & 273.3 & 13,332 & 227.9 & 0 & - & 0 & - & 0 & - & 0 & - & 13,356 & 228.0 \\
\hline III & 4 & 155.0 & 6,248 & 216.5 & 0 & - & 12 & 170.0 & 0 & - & 0 & - & 6,264 & 216.3 \\
\hline IV & 440 & 203.5 & 1,420 & 215.8 & 20 & 186.0 & 0 & - & 0 & - & 4 & 215 & 1,884 & 212.6 \\
\hline
\end{tabular}




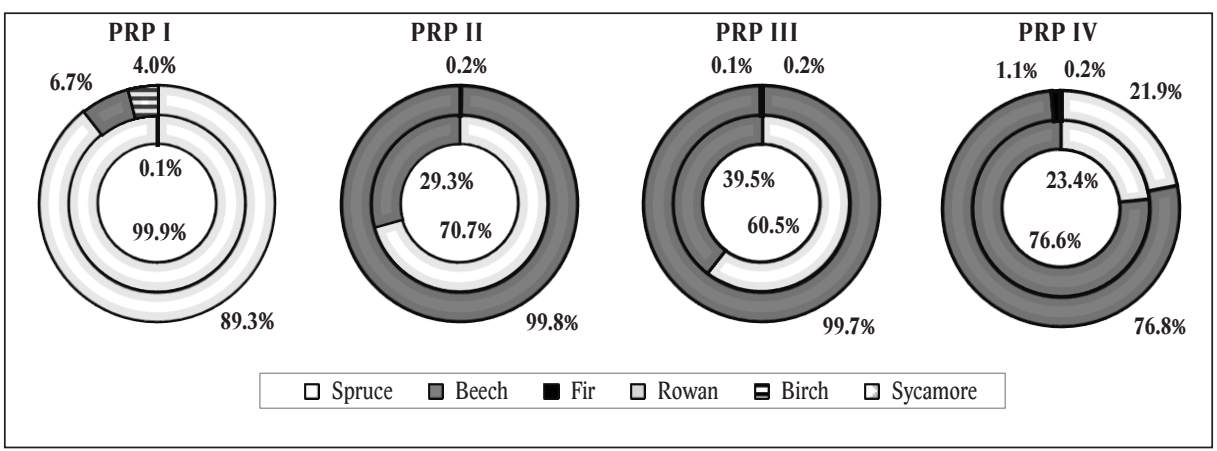

Fig. 7. Percentage proportions of tree species composition of natural regeneration (height $\geq 150 \mathrm{~cm}$ and $\mathrm{DBH}<4 \mathrm{~cm}$ ) according to number of individuals (outer circle), and trees $\left(\mathrm{DBH} \geq 4 \mathrm{~cm}\right.$ ) according to stand volume in $\mathrm{m}^{3}$ (inner circle).

birch $0-4 \%$. Comparing tree species composition of natural regeneration to tree layer, significant expanse of beech regeneration was observed on all PRP (increase up to $71 \%$ ) to the detriment of spruce and occurrence of admixed tree species (silver fir, sycamore maple, silver birch, rowan).

Evaluating species diversity of natural regeneration, species richness $D$ was low on PRP I-III ( $0.105-0.229)$ and medium on PRP IV (0.398; Table 7). Entropy $H^{\prime}$ index showed minimum species heterogeneity on PRP II and III (0.013-0.019) and medium diversity on PRP I and IV $(0.410-0.614)$. Species evenness $E$ was minimum on PRP II and III $(0.018-0.019)$ and medium on PRP I and IV $(0.373-0.443)$. Height differentiation $T M_{h}$ was medium on PRP I and IV $(0.340-0.483)$ and high on PRP II and III (0.502 - 0.558). Comparing natural regeneration and tree layer, higher diversity in natural regeneration was in species richness (+45\%) and height differentiation $(+106 \%)$, while species evenness was higher $(+212 \%)$ in tree layer due to low occurrence of tree species. The spatial pattern of natural regeneration was significantly aggregated on all plots (Table 7). The clumpy pattern of recruits according to their distance (spacing) was indicated by Ripley's $L$-function. Higher aggregation of recruits was proved in beech compared to spruce.

Table 7. Indices describing the diversity of natural regeneration on permanent research plots.

\begin{tabular}{lccccccc}
\hline PRP & D (Mai) & $\mathrm{H}^{\prime}(\mathrm{Si})$ & $\mathrm{E}(\mathrm{Pii})$ & $\mathrm{TMh}(\mathrm{Fi})$ & $\alpha(\mathrm{P} \& \mathrm{Mi})$ & $\mathrm{R}(\mathrm{C} \& \mathrm{Ei})$ & $\mathrm{CS}(\mathrm{D} \& \mathrm{Mi})$ \\
\hline I & 0.267 & 0.410 & 0.373 & 0.483 & $4.159^{*}$ & $0.612^{*}$ & $9.507^{*}$ \\
II & 0.105 & 0.013 & 0.019 & 0.558 & $10.515^{*}$ & $0.701^{*}$ & $26.248^{*}$ \\
III & 0.229 & 0.019 & 0.018 & 0.502 & $16.169^{*}$ & $0.545^{*}$ & $24.846^{*}$ \\
IV & 0.398 & 0.614 & 0.443 & 0.340 & $27.872^{*}$ & $0.546^{*}$ & $10.290^{*}$ \\
\hline
\end{tabular}

Notes: D - species richness index, $\mathrm{H}^{\prime}$ - species heterogeneity index (entropy), E - species evenness index, $\mathrm{TM}_{\mathrm{b}}$ - height differentiation index, $\alpha$ - index of non-randomness, $\mathrm{R}$ - aggregation index, CS - index of cluster size.

* statistically significant $(\mathrm{p}>0.05)$ for horizontal structure (in all cases aggregation).

The mean height of recruits from 1.5 m was comparable on all plots, showing a left-skewed distribution. Mean height of natural regeneration ranged from 199 to 228

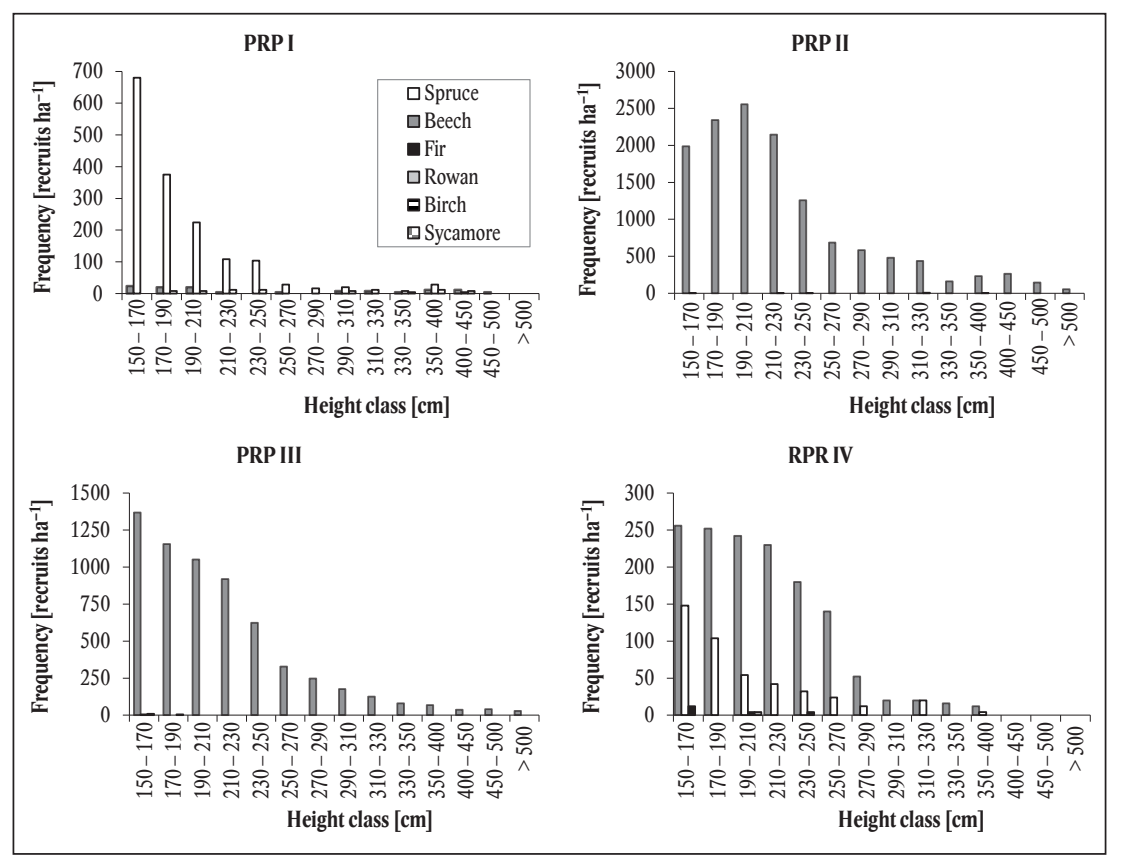

Fig. 8. Histogram of the height structure of natural regeneration according to tree species on permanent research plots in 2016. 
$\mathrm{cm}$, for beech it was from 216 to $262 \mathrm{~cm}$, in spruce 155 -273 , in fir $186 \mathrm{~cm}$, sycamore maple $215 \mathrm{~cm}$ and rowan $170 \mathrm{~cm}$. The growth pattern of heights reached by natural regeneration according to tree species was similar on all plots. On all PRP the most frequent was first height class $(150-170 \mathrm{~cm})$ except advanced natural regeneration on PRP II (Fig. 8).

Mean damage by browsing and bark stripping caused by red deer (Cervus elaphus L.) was low on natural regeneration on PRP $(<5 \%)$, especially in spruce $(2 \%)$ and in beech (6\%). However, the opposite situation was in admixed tree species, the browsing of the leading shoot in silver fir amounted to $68 \%$, in rowan to $82 \%$ and growth of sycamore maple was completely eliminated by game (damage 100\%).

In relation to mature stands, the spatial relationships between natural regeneration and tree layer expressed by the pair correlation function was as random at distances longer than $2 \mathrm{~m}$, only on PRP I it was so from $5 \mathrm{~m}$. At shorter distances the pattern was significantly regular on all PRP that it indicated a negative influence of the tree layer on natural regeneration (Fig. 9).

\section{Discussion}

In recent years, relatively few studies have been published in Central Europe that deal with close-to-nature silviculture and forest transformation according to the guidelines of shelterwood or selection management system (Schütz 2001; Sterba \& Zingg 2001; Souček 2002; Švec et al. 2015). Stand transformations are very important for sustainable forestry and contribute indirectly to faster adaptation to the climate change (Schelhaas et al. 2015). Mixed and structurally diversified stands compared to monospecific stands with homogenous stand structure are more resistant to disturbances (Metz et al. 2016). Moreover, diversification of silvicultural measures should allow both achieving production targets and maintaining biological and ecological diversity (Bergeron et al. 1999).

In studied PRP in the initial stage of transformation, the stand volume ranged from 441 to $731 \mathrm{~m}^{3} \mathrm{ha}^{-1}$, while beech and spruce were dominant tree species. Similar stand volume was reported from mountain forest in Central Europe (von Oheimb et al. 2005; Bulušek et al. 2016; Králíček et al. 2017). On the other hand, significantly higher stand volume (up to $1,237 \mathrm{~m}^{3} \mathrm{ha}^{-1}$ ) was reported from Uholka Ukrainian beech virgin forest (Trotsiuk et al. 2012 ). The volume of dead wood on study plots reached on average $16 \mathrm{~m}^{3} \mathrm{ha}^{-1}$. E.g. Hobi et al. (2015) and Kucbel (2012) reported the average volume of dead wood $136 \mathrm{~m}^{3} \mathrm{ha}^{-1}$, resp. $169 \mathrm{~m}^{3} \mathrm{ha}^{-1}$.

Biodiversity as an important factor plays a key role in all ecosystem components (Pimm et al. 2014; Bílek et al. 2016; Schulze et al. 2016). The results documented the medium- to very strongly diversified vertical structure of investigated stands. Complex stand diversity showed a mostly uneven structure while species richness was low. Natural regeneration reached higher values instead of species heterogeneity. Among the particular plots, PRP I differed by the presence of beech only in small diameter classes due to initial stage of transformation of monospecific spruce forest stand, and low biodiversity unlike the other PRP. These results are generally consistent with Gao et al. (2014), who demonstrated that old stands with multi-layered structure usually have higher species diversity. Mölder et al. (2008) or Barbier et al. (2009) considered the effects of several factors like age, canopy density and species composition as biodiversity determinants. Bílek et al. (2016) stated that biodiversity is influenced by forest management while Heinrichs and Schmidt (2009) directly confirmed an increase in stand diversity after a tending treatment contrary to stands without management.

The horizontal structure of the tree layer in our study was moderately regular, especially at short distances. Random pattern of trees was evident at higher distances,

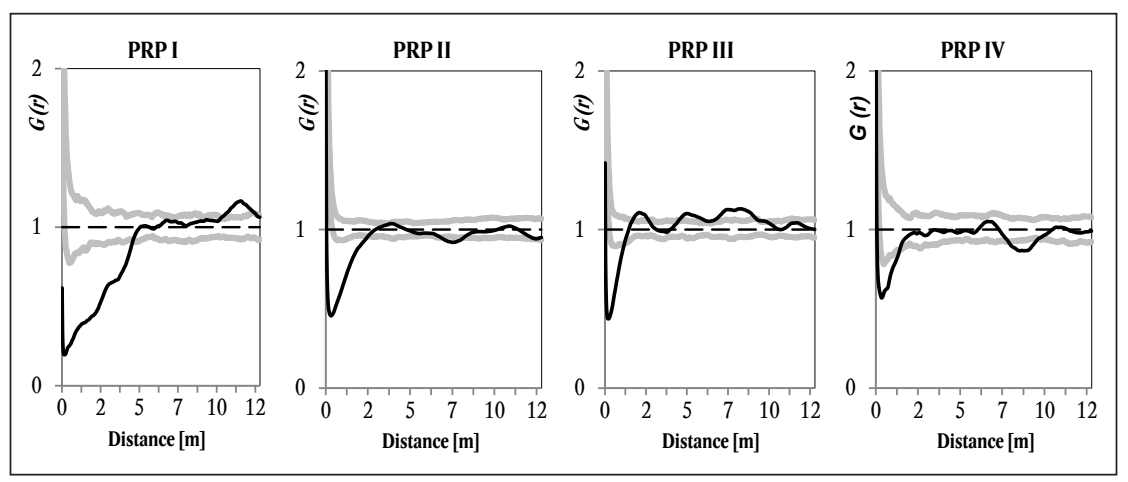

Fig. 9. Spatial distribution of natural regeneration in relation to mature trees on particular permanent research plots expressed by the cross-type pair correlation function; the bold black line represents real distances of individuals; the dashed black line on the level of $G(r)=1$ represents the mean course for random spatial distribution of trees and the two grey curves $95 \%$ confidence interval; when the observed value exceeds the upper (lower) limit of the simulation interval, it indicates significant aggregation - positive relationship (regularity - negative relationship). 
such a prevailing random pattern in spruce-beech forest in Orlické hory Mts. (Králíček et al. 2017). However, in some studies clumpy pattern was reported (von Oheimb et al. 2005), that is usually the result of extreme sites conditions or growth of natural regeneration in canopy gaps (Sefidi et al. 2007; Bulušek et al. 2016). In our research aggregated horizontal structure of regeneration prevailed similar to studies of Ambrož et al. (2015) and Králíček et al. (2017).

Average tree-ring width on the studied PRP was nearly the same in spruce $(1.4-1.6 \mathrm{~mm})$ and in beech $(1.3-1.6 \mathrm{~mm})$. Radial increment of spruce and beech from 0.5 to $1.5 \mathrm{~mm}$ was similar in the Orlické hory Mts. (Králíček et al. 2017). Higher radial increment of spruce compared to beech in spruce-beech stands was reported in southern Sweden (Bolte et al. 2010). The dominant diameter increment of spruce has decreased in the last 50 years, but in beech it has been relatively balanced. The growth depression of spruce particularly from 1980 to 1982 was caused by the synergism of air pollutants (especially $\mathrm{SO}_{2}$ concentrations), climate and bark beetle outbreaks. In fact, 1980 was the coldest year within the cold period $1960-2016\left(2.3^{\circ} \mathrm{C}\right.$, mean $\left.3.8^{\circ} \mathrm{C}\right)$ followed by the extreme dryyear 1982 (795 mm, mean 1220). There were strong attacks of bark beetles in 1992-1997 with subsequent high radial increment due to better light availability. In beech decrease of radial growth in 1997 and 2012 was the effect of damage to beech crowns by icing and wet snow in the winter seasons 1996/1997 and 2011/2012. In April 1997 mean temperature reached $-0.3{ }^{\circ} \mathrm{C}$ (mean in $1960-20162.6^{\circ} \mathrm{C}$ ). In spring 2012 the assimilating organs were damaged by late frost and by the subsequent mass outbreak of gall midge (Mikiola fagi). These results were confirmed also by other authors (Alles 1994; Vacek et al. 2015a; Králíček et al. 2017). A decrease in the radial growth of spruce in 2004-2015 in comparison with the years 1999-2003 was a result of precipitation decrease and increased temperatures. Generally, spruce was more sensitive to negative pointer years with extreme low radial growth compared to beech. Radial growth of spruce was also in significant negative correlation with $\mathrm{SO}_{2}$ and $\mathrm{NO}_{\mathrm{X}}$ concentrations (no effect in beech), such as in other studies (Hauck et al. 2012; Králíček et al. 2017; Putalová et al. 2019). Moreover, spruce was damaged by insect pests and fungal pathogens to a larger extent (Bolte et al. 2010; Maaten-Theunissen \& Bouriaud 2012). The competitiveness of beech in relation to spruce is higher. In our study, spruce was more resistant to air pollution and climatic stress in mixed beech dominant stand on PRP IV compared to spruce monospecific PRP I. Similarly, both species showed higher increment and resistance in mixtures compared to monocultures in Germany (Pretzsch et al. 2014).

Natural regeneration as an important component of close-to-nature management (Štícha et al. 2010; Bílek et al. 2014; Vacek et al. 2017b) was evaluated on all PRP. The number of recruits was in the range of 1,800
$-13,400$ recruits ha ${ }^{-1}$, that it is as higher density compared to spruce-beech forest in Orlické hory Mts. (Vacek et al. 2014b) or in north-eastern Germany (von Oheimb et al. 2005). The abundance of natural regeneration is mainly influenced by the quantity of seeds from the seed bank, successful germination and subsequent survival and growth of seedlings (Sagnard et al. 2007; Wagner et al. 2010). However, many factors are essential for subsequent survival and growth of natural regeneration in forest stands; among them, decreased stand canopy, sufficient light and favourable climatic conditions are the most important (Klopcic \& Boncina 2010; Vacek et al. 2015b). Natural regeneration of spruce has similar requirements when spruce requires more light than beech (Úradníček et al. 2009). It coincides with the negative influence of the tree layer on spatial pattern of natural regeneration confirmed by our study in at short distances lower than 2 to $5 \mathrm{~m}$. Similar conclusions were drawn by Králíček et al. (2017) and Slanař et al. (2017), but in extreme conditions the influence of tree layer may be positive (Vacek \& Hejcman 2012; Bulušek et al. 2016).

In terms of tree species, natural regeneration shows significant increase of beech and decrease of spruce compared to mature tree species composition in study sites. Expansion of beech regeneration was also observed at higher altitudes (Dulamsuren et al. 2017; Vacek et al. 2017b). Not only changing climatic conditions, but also game pressure significantly influence tree species composition in natural regeneration. Game damage is one of the main factors driving species composition of naturally regenerated forests (Roth 1996; Weisberg \& Bugmann 2003; Bernard et al. 2017). Although 90-120 ungulates are hunted in a study forestry section, regeneration of silver fir (68\%), rowan (82 \%) and especially sycamore maple (100\% damage) was heavily or completely eliminated by red deer. On the contrary, the lowest browsing damage was caused to spruce (2\%) and beech (6\%). Thus, in the study area, beech is the only one perspective deciduous tree species that is able to escape strong pressure of ungulates. Considerable silviculture care of the beech crowns has had a positive impact in terms of beech masting and natural regeneration. Unlike the beech, this type of management has not had a real impact on sycamore and fir due to decimation of natural regeneration by ungulates. The attractiveness of fir, rowan and sycamore for game was also confirmed in other part of Czechia (Vacek et al. 2014a, b, 2018), Slovakia (Konôpka \& Pajtík 2015), Germany (Ammer 1996) and Italy (Motta 2003). The recommendation for limiting the game damage and protection of valuable admixed tree species is reduction of still increasing ungulate population, building of overwinter preserve, feeding of game in selected localities, reliable fencing of stands, establishing of fields for game or reintroduction of predators (Vrška et al. 2001; Konôpka et al. 2015; Cukor et al. 2017; Vacek 2017; Cukor et al 2019). 


\section{Conclusions}

Forest managers should make use of the possibilities of adaptation on climatic change with maximum involvement of natural processes. These modern silvicultural approaches should be directed at sustainable, ecologically and socio-economically acceptable forest development in the future. This study shows that beech is at altitudes of $640-810 \mathrm{~m}$ a.s.l. generally more resistant tree species than spruce. Spruce is more resistant to unfavourable environmental conditions (pollution and climatic extremes) in admixtures compared to monospecific stands. In terms of climate change, it is necessary to support resistance of forest to extreme climate evens by increasing structural diversity and retaining species richness. It must be outlined that the studied forest stands are at the beginning of forest transformation with emphasis on production, ecological stability and biodiversity under ongoing global climate change. Based on our results the set silvicultural strategy leads despite the considerable pressure of ungulates to the formation of stable mixed forests able to mitigate climate change.

\section{Acknowledgments}

This study was supported by the Ministry of Agriculture of the Czech Republic (NAZVNo. QK11910292) and by the CzechUniversity of Life Sciences Prague, Faculty of Forestry and Wood Sciences (IGA No. B03/18).

\section{References}

Ambrož, R., Vacek, S., Vacek, Z., Král, J., Štefančík, I., 2015: Current and simulated structure, growth parameters and regeneration of beech forests with different game management in the Lány Game Enclosure. Central European Forestry Journal, 61:78-88.

Ammer, C., 1996: Impact of ungulates on structure and dynamics of natural regeneration of mixed mountain forests in the Bavarian Alps. Forest Ecology and Management, 88:43-53.

Barbati, A., Marchetti, M., Chirici, G., Corona, P., 2014: European forest types and forest Europe SFM indicators: tools for monitoring progress on forest biodiversity conservation. Forest Ecology and Management, 321:145-157.

Barbier, S., Chevalier, R., Loussot, P., Bergès, L., Gosselin, F., 2009: Improving biodiversity indicators of sustainable forest management: Tree genus abundance rather than tree genus richness and dominance for understory vegetation in French lowland oak hornbeam forests. Forest Ecology and Management, 258:176-186.

Barna, M., Bošela, M. 2015: Tree species diversity change in natural regeneration of a beech forest under different management. Forest Ecology and Management, 342:93-102.
Bergeron, Y., Harvey, B., Leduc, A., Gauthier, S., 1999: Forest management guidelines based on natural disturbance dynamics: stand-and forest-level considerations. Forestry Chronicle, 75:49-54.

Bernard, M., Boulanger, V., Dupouey, J. L., Laurent, L., Montpied, P., Morin, X., et al. 2017: Deer browsing promotes Norway spruce at the expense of silver fir in the forest regeneration phase. Forest Ecology and Management, 400:269-277.

Bílek, L., Remeš, J., Podrázský, V., Rozenbergar, D., Diaci, J., Zahradník, D., 2014: Gap regeneration in near-natural European beech forest stands in Central Bohemia - the role of heterogeneity and microhabitat factors. Dendrobiology, 71:59-71.

Bílek, L., Remeš, J., Zahradník, D., 2011: Managed versus unmanaged. Structure of beech forest stands" Fagus sylvatica L." after 50 years of development, Central Bohemian. Forest Systems, 1:122-138.

Bílek, L., Vacek, S., Vacek, Z., Remeš, J., Král, J., Bulušek, D., Gallo, J., 2016: How close to nature is close-to-nature pine silviculture? Journal of Forest Science, 62:24-34.

Bilela, S., Dounavi, A., Fussi, B., Konnert, M., Holst, J., Mayer, H. et al., 2012: Natural regeneration of Fagus sylvatica L. adapts with maturation to warmer and drier microclimatic conditions. Forest Ecology and Management, 275:60-67.

Bolte, A., Czajkowski, T., Kompa, T., 2007: The northeastern distribution range of European beech - a review. Forestry, 80:413-429.

Bolte, A., Hilbrig, L., Grundmann, B., Kampf, F., Brunet, J., Roloff, A., 2010: Climate change impacts on stand structure and competitive interactions in a southern Swedish spruce-beech forest. European Journal of Forest Research, 129:261-276.

Bošela, M., Štefančík, I., Petráš, R., Vacek, S., 2016: The effects of climate warming on the growth of European beech forests depend critically on thinning strategy and site productivity. Agricultural and Forest Meteorology, 222:21-31.

Briner, S., Elkin, C., Huber, R., 2013: Evaluating the relative impact of climate and economic changes on forest and agricultural ecosystem services in mountain regions. Journal of Environmental Management, 129:414-422.

Bulušek, D., Vacek, Z., Vacek, S., Král, J., Bílek, L., Králíček, I., 2016: Spatial pattern of relict beech (Fagus sylvatica L.) forests in the Sudetes of the Czech Republic and Poland. Journal of Forest Science, 62:293-305.

Butler, K. F., Koontz, T. M., 2005: Theory into practice: implementing ecosystem management objectives in the USDA Forest Service. Environmental Management, 35:138-150.

Cardinall, D., Hammond, H., Holt, R., Moore, K., Beese, B., Ruitenbeek, J. et al., 2004: Ecosystem-Based Management Planning Handbook. Coast Information Team, Victoria, BC, 80 p. 
Chianucci, F., Salvati, L., Giannini, T., Chiavetta, U., Corona, P., Cutini, A., 2016: Long-term response to thinning in a beech (Fagus sylvatica L.) coppice stand under conversion to high forest in Central Italy. Silva Fennica, 50:1549-1558.

Clark, P. J., Evans, F. C., 1954: Distance to nearest neighbour as a measure of spatial relationship in populations. Ecology, 35:445-453.

Cukor, J., Havránek, F., Rohla, J., Bukovjan, K., 2017: Stanovení početnosti jelení zvěře v západní části Krušných hor. Zprávy lesnického výzkumu, 62:288295.

Cukor, J., Vacek, Z., Linda, R., Vacek, S., Marada, P., Šimůnek, V., Havránek, F., 2019: Effects of bark stripping on timber production and structure of Norway spruce forests in relation to climatic factors, Forests, 10:320.

Drobyshev, I., Niklassona, M., Mazerolled, M. J., Bergeron, Y., 2014: Reconstruction of a 253-year long mast record of European beech reveals its association with large scale temperature variability and no long-term trend in mast frequencies. Agricultural and Forest Meteorology, 192-193:9-17.

Dulamsuren, C., Hauck, M., Kopp, G., Ruff, M., Leuschner, C., 2017: European beech responds to climate change with growth decline at lower, and growth increase at higher elevations in the center of its distribution range (SW Germany). Trees - Structure and Function, 31:673-686.

Ellenberg, H., 1996: Vegetation Mitteleuropas mit den Alpen, 5th edition. Ulmer, Stuttgart, 1095 p.

Fabrika, M., Ďurský, J., 2005: Algorithms and software solution of thinning models for SIBYLA growth simulator. Journal of Forest Science, 51:431-445.

FAO, 2006: Global Forest Resource Assessment 2005 Progress Towards Sustainable Forest Management. FAO Forestry Paper 147.

Flechard, C. R., Nemitz, E., Smith, R., Fowler, D., Vermeulen, A. T., Bleeker, A. et al., 2011: Dry deposition of reactive nitrogen to European ecosystems: a comparison of inferential models across the NitroEurope network. Atmospheric Chemistry and Physics, 11:2703-2728.

Fotelli, M. N., Rennenberg, H., Holst, T., Mayer, H., Gessler, A., 2003: Carbon isotope composition of various tissues of beech (Fagus sylvatica) regeneration is indicative of recent environmental conditions within the forest understorey. New Phytologist, 159:229-244.

Füldner, K., 1995: Strukturbeschreibung in Mischbeständen. Forstarchiv, 66:235-606.

Gao, T., Hedblom, M., Emilsson, T., Nielsen, A. B., 2014: The role of forest stand structure as biodiversity indicator. Forest Ecology and Management, 330:82-93.

Gessler, A., Keitel, C., Kreuzwieser, J., Matyssek, R., Seiler, W., Rennenberg, H., 2007: Potential risk of European beech (Fagus sylvatica L.) in a changing climate. Trees, 21:1-11.
Grodzki, W., 2010: The decline of Norway spruce Picea abies (L.) Karst. stands in Beskid Ślaski and Zywiecki: Theoretical koncept and reality. Beskydy, 3:19-26.

Harmon, M. E., Franklin, J. F., Swanson, F. J., Sollins, P., Gregory, S. V., Lattin, J. D. et al., 1986: Ecology of Coarse Woody Debris in Temperate Ecosystems. Advances in Ecological Research, 15:133-302.

Hauck, M., Zimmermann, J., Jacob, M., Dulamsuren, C., Bade, C., Ahrends, B. et al., 2012: Rapid recovery of stem increment in Norway spruce at reduced $\mathrm{SO}_{2}$ levels in the Harz Mountains, Germany. Environmental pollution, 164:132-141.

Heinrichs, S., Schmidt, W., 2009: Short-term effects of selection and clear cutting on the shrub and herb layer vegetation during the conversion of even-aged Norway spruce stands into mixed stands. Forest Ecology and Management, 258:667-678.

Hlásny, T., Sitková, Z. (eds.), 2010: Spruce forests decline in the Beskids. National Forest Centre-Forest Research Institute Zvolen, Czech University of Life Sciences Prague, Forestry and Game Management Research Institute Jíloviště-Strnady, Zvolen, 182 p.

Hlásny, T., Barka, I., Rößiger, J., Kulla, L., Trombik, J., Sarvašová, Z. et al., 2017: Conversion of Norway spruce forests in the face of climate change: a case study in Central Europe. European Journal of Forest Research, 136:1013-1028.

Hobi, M. L., Commarmot, B., Bugmann, H., 2015: Pattern and process in the largest primeval beech forest of Europe (Ukrainian Carpathians). Journal of Vegetation Science, 26:323-336.

Hopkins, B., Skellam, J. G., 1954: A new method for determining the type of distribution of plant individuals. Annals of Botany, 18:213-227.

IPCC, 2007: Climate change 2007: the physical science basis. In: Solomon, S., Qin, D., Manning, M., Chen, Z., Marquis, M., Averyt, K. B. et al. (eds.): Contribution of Working Group I to the Fourth Assessment Report of the Intergovernmental Panel on Climate Change. Cambridge University Press, Cambridge, $996 \mathrm{p}$.

Jaehne, S. C., Dohrenbusch, A., 1997: Ein Verfahren zur Beurteilung der Bestandesdiversität. Forstwissenschaftliches Centralblatt, 116:333-345.

Jantsch, M. C., Fischer, H. S., Winter, S., Fischer, A., 2013: How are plant species in central European beech (Fagus sylvatica L.) forests affected by temperature changes? Shift of potential suitable habitats under global warming. Annals of Botany, 4:97-113.

Jirgle, J., Kučera, J., Tichý, J., Materna, J., 1983: Poškození lesů v Jizerských horách imisemi. Zprávy lesnického výzkumu, 28:16-24.

Jönsson, A. M., Schroeder, L. M., Lagergren, F., Anderbrant, O., Smith, B., 2012: Guess the impact of Ips typographus - an ecosystem modelling approach for simulating spruce bark beetle outbreaks. Agricultural and Forest Meteorology, 166-167:188-200. 
Klopcic, M., Boncina, A., 2010: Patterns of tree growth in a single tree selection silver fir-European beech forest. Journal of Forest Research, 15:21-30.

Kolář, T., Čermák, P., Trnka, M., Žid, T., Rybníček, M., 2017: Temporal changes in the climate sensitivity of Norway spruce and European beech along an elevation gradient in Central Europe. Agricultural and Forest Meteorology, 239:24-33.

Köppen, W., 1936: Das Geographische System der Klimate, Handbuch der Klimatologie. Gebrüder Borntraeger, Berlin.

Konôpka, J., Kaštier, P., Konôpka, B., 2015: Teoretické východiská a praktické opatrenia na harmonizáciu záujmov lesného hospodárstva a polovníctva na Slovensku. Lesnícky časopis - Forestry Journal, 61:114-123.

Konôpka, B., Pajtík, J., 2015: Why was browsing by red deer more frequent but represented less consumed mass in young maple than in ash trees?! Journal of Forest Science, 61:431-438.

Králíček, I., Vacek, Z., Vacek, S., Remeš, J., Bulušek, D., Král, J. et al., 2017: Dynamics and structure of mountain autochthonous spruce-beech forests: impact of hilltop phenomenon, air pollutants and climate. Dendrobiology, 77:121-139.

Krejčí, F., Vacek, S., Bílek, L., Mikeska, M., Hejcmanová, P., Vacek, Z., 2013: The effects of climatic conditions and forest site types on disintegration rates in Picea abies occurring at the Modrava Peat Bogs in the Šumava National Park. Dendrobiology, 70:35-44.

Kucbel, S., Saniga, M., Jaloviar, P., Vencurik, J., 2012: Stand structure and temporal variability in oldgrowth beech-dominated forests of the northwestern Carpathians: A 40-years perspective. Forest Ecology and Management, 264:125-133.

Lorz, C., Fürst, C., Galic, Z., Matijasic, D., Podrázký, V., Potocic, N. et al., 2010: GIS-based probability assessment of natural hazards in forested landscapes of central and south-eastern Europe. Environmental Management, 46:920-930.

Machar, I., Vlčková, V., Buček, A., Voženílek, V., Šálek, L., Jeřabková, L., 2017: Modelling of climate conditions in forest vegetation zones as a support tool for forest management strategy in European beech dominated forests. Forests, 8:82-99.

Margalef, D. R., 1958: Information theory in ecology. International Journal of General Systems, 3:36-71.

Metz, J., Annighöfer, P., Schall, P., Zimmermann, J., Kahl, T., Schulze, E.-D. et al., 2016: Site-adapted admixed tree species reduce drought susceptibility of mature European beech. Global Change Biology, 22:903-920.

Ministerial Conference on the Protection of Forests in Europe, 2015: Madrid Ministerial Declaration 25 years together promoting Sustainable Forest Management in Europe. Madrid 20-21 October 2015, $156 \mathrm{p}$.
Ministerstvo zemědělství 2018: Zpráva o stavu lesa a lesního hospodářství České republiky v roce 2017. Ministerstvo zemědělství, Praha, 118 p.

Mölder, A., Bernhardt-Römermann, M., Schmidt, W., 2008: Herb-layer diversity in deciduous forests: raised by tree richness or beaten by beech? Forest Ecology and Management, 256:272-281.

Mountford, M. D., 1961: On E. C. Pielou's index of non randomness. Journal of Ecology, 49:271-275.

Motta, R., 2003: Ungulate impact on rowan (Sorbus aucuparia L.) and Norway spruce (Picea abies (L.) Karst.) height structure in mountain forests in the eastern Italian Alps. Forest Ecology and Management, 181:139-150.

Neuner, S., Albrecht, A., Cullmann, D., Engels, F., Griess, V. C., Hahn, W. A. et al., 2014: Survival of Norway spruce remains higher in mixed stands under a dryer and warmer climate. Global Change Biology, 21:935-946.

Packham, J. R., Thomas, P. A., Atkinson, M. D., Degen, T., 2012: Biological Flora of the British Isles: Fagus sylvatica. Journal of Ecology, 100:1557-1608.

Petráš, R., Pajtík, J., 1991: Sústava česko-slovenských objemových tabuliek drevín. Lesnícky časopis, 37:49-56.

Petritan, I. C., Commarmot, B., Hobi, M. L., Petritan, A. M., Bigler, C., Abrudan, I. V. et al., 2015: Structural patterns of beech and silver fir suggest stability and resilience of the virgin forest Sinca in the Southern Carpathians, Romania. Forest Ecology and Management, 356:184-195.

Petritan, A. M., von Lüpke, B., Petritan, I. C., 2009: Influence of light availability on growth, leaf morphology and plant architecture of beech (Fagus sylvatica L.), maple (Acer pseudoplatanus L.) and ash (Fraxinus excelsior L.) saplings. European Journal of Forest Research, 128:61-74.

Pielou, E.C., 1975: Ecological Diversity. Wiley, New York, $165 \mathrm{p}$.

Pimm, S. L., Jenkins, C. N., Abell, R., Brooks, T. M., Gittleman, J. L., Joppa, L. N. et al., 2014: The biodiversity of species and their rates of extinction, distribution, and protection. Science, 344:987.

Poleno, Z., Vacek, S., Podrázský, V., Remeš, J., Štefančík, I., Mikeska, M. et al., 2009: Pěstování lesů III. Praktické postupy pěstování lesů. Kostelec nad Černými lesy, Lesnická práce, 952 p.

Pretzsch, H., 2006: Wissen nutzbar machen für das Management von Waldökosystemen. Allgemeine Forstzeitschrift/Der Wald, 61:1158-1159.

Pretzsch, H., Rötzer, T., Matyssek, R., Grams, T. E. E., Häberle, K. H., Pritsch, K. et al., 2014: Mixed Norway spruce (Picea abies [L.] Karst) and European beech (Fagus sylvatica [L.]) stands under drought: from reaction pattern to mechanism. Trees, 28:13051321. 
Puettmann, K. J., Wilson, S. M., Baker, S. C., 2015: Silvicultural alternatives to conventional even-aged forest management - what limits global adoption? Forest Ecosystems, 2:8.

Putalová, T., Vacek, Z., Vacek, S., Štefančík, I., Bulušek, D., Král, J., 2019. Tree-ring widths as an indicator of air pollution stress and climate conditions in different Norway spruce forest stands in the Krkonoše Mts. Central European Forestry Journal, 65:21-33.

Remeš, J., Bílek, L., Novák, J., Vacek, Z., Vacek, S., Putalová, T. et al., 2015: Diameter increment of beech in relation to social position of trees, climate characteristics and thinning intensity. Journal of Forest Science, 61:456-464.

Roth, R., 1996: The effect of deer on the natural regeneration of mixed forests. Zeitschrift fur Jagdwissenschaft, 42:143-156.

Sagnard, F., Pichot, C., Dreyfus, P., Jordano, P., Fady, B., 2007: Modelling seed dispersal to predict seedling recruitment: recolonization dynamics in a plantation forest. Ecological Modelling, 203:464-474.

Sefidi, K., Marvi Mohadjer, M. R., Zobeiri, M., Etemad, V., 2007: Investigation on dead trees effects on natural regeneration of Oriental beech and hornbeam in a mixed beech forest. Iranian Journal of Forest and Poplar Research, 15:365-373.

Seidl, R., Schelhaas, M. J., Rammer, W., Verkerk, P. J., 2014: Increasing forest disturbances in Europe and their impact on carbon storage. Nature Climate Change, 4:806-810.

Shahverdi, M., Dashti, H., Taghiyari, H. R., Heshmati, S., Gholamiyan, H., Hossein, M. A., 2013: The Impact of red heartwood on drying characteristics and mass transfer coefficients in beech wood. Austrian Journal of Forest Science, 130:85-101.

Shannon, C. E., 1948: A mathematical theory of communications. Bell System Technical Journal, 27:379_ 423.

Schelhaas, M. J., Nabuurs, G. J., Hengeveld, G., Reyer, C., Hanewinkel, M., Zimmermann, N. E. et al., 2015: Alternative forest management strategies to account for climate change-induced productivity and species suitability changes in Europe. Regional Environmental Change, 15:1581-1594.

Schulze, E. D., Aas, G., Grimm, G. W., Gossner, M. M., Walentowski, H., Ammer, C. et al., 2016: A review on plant diversity and forest management of European beech forests. European Journal of Forest Research, 135:51-67.

Schütz, J. P., 1999: Close-to-nature silviculture: is this concept compatible with species diversity? Forestry, 72:359-366.

Schütz, J.P., 2001: Opportunities and strategies of transforming regular forests to irregular forests. Forest Ecology and Management, 151:87-94.

Schütz, J. P., 2002: Silvicultural tools to develop irregular and diverse forest structures. Forestry, 75:329-337.
Slanař, J., Vacek, Z., Vacek, S., Bulušek, D., Cukor, J., Štefančík, I. et al., 2017: Long-term transformation of submontane spruce-beech forests in the Jizerské hory Mts.: dynamics of natural regeneration. Central European Forestry Journal, 63:212-224.

Souček, J., 2002: Conversion of forest managed under systems involving coupes to a selection forest on an example of the Opuky research area. Journal of Forest Science, 48:1-7.

Spiecker, H., Hansen, J., Klimo, E., Skovsgaard, J. P., Sterba, H., von Teuffel, K., 2004: Norway spruce conversion - options and consequences. Brill, Leiden.

Sterba, H., Zingg, A., 2001: Target diameter harvesting - a strategy to convert even-aged forests. Forest Ecology and Management, 151:95-105.

Šmilauer, P., Lepš, J., 2014: Multivariate analysis of ecological data using CANOCO 5. Cambridge university press, $361 \mathrm{p}$.

Švec, O., Bílek, L., Remeš, J., Vacek, Z., 2015:Analysis of operational approach during forest transformation in Klokočná Range, Central Bohemia. Journal of Forest Sciences, 61:148-155.

Štícha, V., Kupka, I., Zahradník, D., Vacek, S., 2010: Influence of micro-relief and weed competition on natural regeneration of mountain forests in the Šumava Mountains. Journal of Forest Science, 56:218-224.

Terek, J., Dobrovič J., 2013: Ecologically active surface, the basis for the study and evaluation of ecological functions. In: 4th International Conference „To Protect Our Global Environment of Future Generation“, Obuda University, Budapest, p. 149-157.

Tesař, V., Klimo, E., Kraus, M., Souček, J., 2004: Dlouhodobá přestavba jehličnatého lesa na Hetlíně - kutnohorské hospodářství. Brno, MZLU v Brně, 60 p.

Trotsiuk, V., Hobi, M. L., Commarmot, B., 2012: Age structure and disturbance dynamics of the relic virgin beech forest Uholka (Ukrainian Carpathians). Forest Ecology and Management, 265:181-190.

Úradníček, L., Maděra, P., Tichá, S., Koblížek, J., 2009: Dřeviny České republiky. Lesnická práce, Kostelec nad Černými lesy.

Urli, M., Thiffault, N., Barrette, M., Bélanger, L., Leduc, A., Chalifour, D., 2017: Key ecosystem attributes and productivity of boreal stands 20 years after the onset of silviculture scenarios of increasing intensity. Forest Ecology and Management, 389:404-416.

Vacek, S., Cipra, Z., 1979: Struktura porostů v biocentru Jedlový důl. Zpráva pro CHKO Jizerské hory. VS Opočno a SCHKO Jizerské hory, 18 p.

Vacek, S., Vančura, K., Zingari, P.C., Jeník, J., Simon, J., Smejkal, J., 2003: Mountain forests of the Czech Republic. Ministry of agriculture of the Czech Republic, Prague, 320 p. 
Vacek, S., Hejcman, M., 2012: Natural layering, foliation, fertility and plant species composition of a Fagus sylvatica stand above the alpine timberline in the Giant (Krkonoše) Mts., Czech Republic. European Journal of Forest Research, 131:799-810.

Vacek, S., Vacek, Z., Podrazský, V., Bílek, L., Bulušek, D., Štefančík, I., 2014a: Structural Diversity of Autochthonous Beech Forests in Broumovské Stěny National Nature Reserve, Czech Republic. Austrian Journal of Forest Science, 131:191-214.

Vacek, S., Hůnová, I., Vacek, Z., Hejcmanová, P., Podrázský, V., Král, J. et al., 2015a: Effects of air pollution and climatic factors on Norway spruce forests in the Orlické hory Mts. (Czech Republic), 1979-2014. European Journal of Forest Research, 134:1127-1142.

Vacek, S., Černý, T., Vacek, Z., Podrázský, V., Mikeska, M., Králíček, I., 2017a: Long-term changes in vegetation and site conditions in beech and spruce forests of lower mountain ranges of Central Europe. Forest Ecology and Management, 398:75-90.

Vacek, S., Vacek, Z., Kalousková, I., Cukor, J., Bílek, L., Moser, W. K. et al., 2018: Sycamore maple (Acer pseudoplatanus L.) stands on former agricultural land in the Sudetes-evaluation of ecological value and production potential. Dendrobiology, 79:61-76.

Vacek, Z., Vacek, S., Bílek, L., Král, J., Remeš, J., Bulušek, D. et al., 2014b: Ungulate Impact on Natural Regeneration in Spruce-Beech-Fir Stands in Černý důl Nature Reserve in the Orlické Hory Mountains, Case Study from Central Sudetes. Forests, 5:2929-2946.

Vacek, Z., Vacek, S., Podrázský, V., Bílek, L., Štefančík, I., Moser, W. K., 2015b: Effect of tree layer and microsite on the variability of natural regeneration in autochthonous beech forests. Polish Journal of Ecology, 63:233-246.
Vacek, Z., 2017: Structure and dynamics of sprucebeech-fir forests in Nature Reserves of the Orlické hory Mts. in relation to ungulate game. Central European Forestry Journal, 63:23-34.

Vacek, Z., Bulušek, D., Vacek, S., Hejcmanová, P., Remeš, J., Bílek, L. et al., 2017b: Effect of microrelief and vegetation cover on natural regeneration in European beech forests in Krkonoše national parks (Czech Republic, Poland). Austrian Journal of Forest Science, 134:75-96.

van der Maaten-Theunissen, M., Bouriaud, O., 2012: Climate-growth relationships at different stem heights in silver fir and Norway spruce. Canadian Journal of Forest Research, 42:958-969.

von Oheimb, G., Westphal, C., Tempel, H., Härdtle, W., 2005: Structural pattern of a near-natural beech (Fagus sylvatica) forest (Serrahn, North-east Germany). Forest Ecology and Management, 212:253263.

Vrška, T., Hort, L., Odehnalová, P., Adam, D., Horal, D., 2001: Boubín virgin forest after 24 years (19721996) - Development of tree layer. Journal of Forest Science, 47:439-456.

Wagner, S., Madsen, P., Ammer, C., 2009: Evaluation of different approaches for modelling individual tree seedling height growth. Trees - Structure and Function, 23:701-715.

Weisberg, P. J., Bugmann, H., 2003: Forest dynamics and ungulate herbivory: from leaf to landscape. Forest Ecology and Management, 181:1-12.

Yamaguchi, D. K., 1991: A simple method for crossdating increment cores from living trees. Canadian Journal of Forest Research, 21:414-416.

Zahradník, D., Puš, V., 2010: Program PoinPro Version 2.2. Czech University of Life Sciences, Prague. 